\title{
Religion and wellbeing around the world: Social purpose, social time, or social insurance?
}

\author{
Carol Graham · Sarah Crown
}

\begin{abstract}
A number of studies find that religious people are happier than non-religious ones. Yet a number of fundamental questions about that relationship remain unanswered. A critical one is the direction of causality: does religion make people happier or are happier people more likely to have faith in something that is beyond their control? We posit that the relationship between religion and wellbeing is mediated by factors ranging from intrinsic purpose, to its social aspects, to its role as an insurance mechanism for people who face great adversity. We explore a number of related questions, using world-wide data from the Gallup World Poll. As these data are crosssection data, we cannot establish causality; we do, however, explore: how or if the relationship between religion and wellbeing varies across the two distinct wellbeing dimensions (hedonic and evaluative); how social externalities mediate the relationship; how the relationship changes as countries and people within them become more prosperous and acquire greater means and agency; and how the relationship between religion and wellbeing varies depending on where respondents are in the wellbeing distribution. We find that the positive relation between religion and evaluative wellbeing is more important for respondents with lower levels of agency, while the positive relation with hedonic wellbeing holds across the board. The social dimension of religion is most important for the least social respondents, while the religiosity component of religion is most important for the happiest respondents, regardless of religious affiliation or service attendance. As such, it seems that the happiest are most likely to seek social purpose in religion, the poorest are most likely to seek social insurance in religion, and the least social are the most likely to seek social time in religion.
\end{abstract}

Keywords: religion, evaluative wellbeing, hedonic wellbeing, agency, social insurance

\section{Introduction}

An important dimension of human experience is religion. A number of studies (including this paper) find that religious people are happier than non-religious ones. In many places, religion has spillover effects for the non-religious. Religion could, for example, enhance wellbeing through the positive effects of participation in religious activities and associated social externalities. Or it could be that the intrinsic beliefs and purpose associated with religion drive the relationship. Religion also plays an important role in providing psychological insurance for individuals coping with health shocks, aging, and adverse and difficult circumstances (such as extreme poverty), among others. That insurance role may help explain a seeming puzzle, meanwhile. At the same time that religious people are happier, religiosity is higher in places that are less happy and less prosperous on average. ${ }^{1}$

\footnotetext{
${ }^{1}$ See, among others, Clark and Lelkes (2005); Clark and Lelkes (2009); Deaton (2009); Deaton and Stone (2013); and Diener, Tay, and Myers (2011).
}

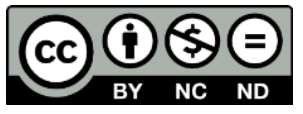

Copyright belongs to the author(s) www.internationaljournalofwellbeing.org 
A number of fundamental questions about the relationship between religion and wellbeing remain unanswered. A critical one is the direction of causality: does religion make people happier or are happier people more likely to have faith in something that is beyond their control? And are religious people happier in the Aristotelian/eudaimonic sense of having purpose and meaning in life, or are they simply happier because having religion makes their day-to-day living more pleasant? Similarly, does having faith bring higher levels of wellbeing, or is it the social externalities associated with religious activities that matter most? Does religion play a role as both psychological and social insurance for those who lack other means and capabilities to deal with adverse conditions? Does the importance of religion change as countries and people within them become more prosperous? While we cannot establish causality due to the cross-section nature of our data, our analysis does yield insights into these questions.

There is a burgeoning literature on wellbeing, much of which finds consistent patterns in its determinants in countries and cultures around the world. Many of these patterns are predictable: income matters to individual wellbeing, but after a certain point other things such as the incomes of others also start to matter. Health is essential to wellbeing, and stable partnerships, stable marriages, and social relationships also play a role. Women are typically happier than men, except in contexts where their rights are severely compromised. And because these patterns are so consistent across diverse countries and cultures, scholars in the field can control for these factors and explore the wellbeing effects of phenomena that vary greatly, such as inflation and unemployment rates; crime and corruption; smoking, drinking, and exercising; and the nature of public goods, among others. Not surprisingly, the approach is well-suited for exploring the relationship between wellbeing and religion. ${ }^{2}$

Wellbeing has two distinct and measurable dimensions, each of which captures different aspects of human lives. ${ }^{3}$ The first is hedonic wellbeing, which captures the manner in which individuals experience their daily lives, the quality of those lives, and their moods (both positive and negative) during those experiences. The second is evaluative wellbeing, which captures how people think about and assess their lives as a whole. The latter dimension implicitly includes eudaimonic wellbeing - how much purpose or meaning people have in their lives - although there are also aspects of daily experiences which can be purposeful but not pleasurable (such as reading the same story over and over again to a child); and others which are pleasurable but not purposeful (such as watching television).

Hedonic wellbeing is typically measured with questions that gauge positive affect on the one hand (smiling yesterday or happy yesterday, for example), and negative affect (anger or stress yesterday) on the other. Psychologists emphasize that there is not a simple continuum running from the positive to negative dimensions, as people can experience both at the same time (such as happiness and stress). ${ }^{4}$ Evaluative wellbeing, meanwhile, is typically measured with questions that ask respondents about their satisfaction with their lives as a whole, or to compare their lives to the best possible life they can imagine.

Evaluative wellbeing typically correlates more closely with individual income than does hedonic wellbeing, not least as life course evaluations extend well beyond momentary experiences and encompass the opportunities and choices that people have in their lives. Graham and Nikolova, for example, find that individuals emphasize one wellbeing dimension over the other, depending on their agency and capabilities. Respondents with more means and greater agency (e.g. the capacity to make choices over the courses that their lives take) tend to emphasize

\footnotetext{
2 See, among others, Frey and Stutzer (2002); Blanchflower and Oswald (2004); Graham (2009); and Graham (2008).

${ }^{3}$ The state of the science on these two dimensions is summed up in: Diener (2012); and Graham (2012).

${ }^{4}$ Diener (2012), among others.
} 
evaluative wellbeing more, while those with limited means and opportunities tend to emphasize daily experience more. They also find that income and agency are less important to the wellbeing of respondents who are at the highest levels of the wellbeing distribution. ${ }^{5}$

In this paper, we posit that the relationship between religion and wellbeing could be similarly mediated by the rationale underlying individual religiosity, which could range from intrinsic purpose, to its social aspects, to its role as an insurance mechanism for people who face great adversity and lack agency. We explore a number of related questions, using world-wide data from the Gallup World Poll. The first is how or if the relationship between religion and wellbeing varies across the two distinct wellbeing dimensions (hedonic and evaluative), and, related to that, how it varies across religions around the world. The second is how socializing/social externalities mediate the relationship. The third is how or if the relationship changes as countries and people within them become more prosperous and acquire more means and greater agency. The fourth is how or if the relationship between religion and wellbeing varies depending on where respondents are in the wellbeing distribution (in other words depending on their happiness levels regardless of religion).

\section{Building on what we know from other studies}

A number of studies by both psychologists and economists find a positive relationship between religion and subjective wellbeing. There is much less clarity on the channels driving this relationship and on the direction of causality.

Some studies find an important role for hedonic wellbeing, highlighting the experience of attending religious services and the associated social externalities. Clark and Lelkes, for example, in a study of Catholics, Protestants, and atheists across Europe, find that both own religious behavior and average religiosity in the region have a positive impact on life satisfaction, even for the non-religious in religious regions. They attribute their findings to the social externalities associated with religiosity, and their results hold even when controlling for social capital, crime, and trust in the respective regions. Steiner, Leinhart, and Frey, meanwhile, find a positive and sizable association between happiness and church-going in Switzerland. Witter et al., basing their conclusions on a meta-analysis of religion and subjective wellbeing in adulthood, find that the positive relation between religion and subjective wellbeing is stronger for religious activity than for religiosity measures, and that it is also stronger for older than younger adults. They also find that the relation in general has decreased over time. ${ }^{6}$

Lim and Putnam, using panel data for a representative sample of U.S. adults in 2006-2009 from the Faith Matters Study, find a strong role for social and participatory mechanisms - regular attendance at services and social networks within congregations - in shaping religion's impact on life satisfaction. Their results are contingent on the presence of a strong religious identity. They find little evidence of a eudaimonic channel in the religion-life satisfaction relationship. ${ }^{7}$

Lim and Putnam's findings on religious identity are supported by research by Mookerjee and Beron that finds an overall positive relationship between religion and wellbeing across countries, but that the relationship is eroded in contexts where religious fractionalization is higher. Along the same lines Graham and Chattopadhyay (2009) find that the positive cross-country relationship between religious affiliation and wellbeing does not hold in contexts where religious identities are strong and divided, as in the case of Afghanistan and Central Asia. ${ }^{8}$

\footnotetext{
${ }^{5}$ Graham and Nikolova (2013).

${ }^{6}$ Clark and Lelkes (2005); Steiner, Leinart, and Frey (2010); Witter, Stock, Okun, and Haring (1985).

${ }^{7}$ Lim and Putnam (2010).

${ }^{8}$ Mookerjee and Beron (2005); and Graham and Chattopadhyay (2009).
} 
Other studies find that the eudaimonic or intrinsic component of religion matters more than the hedonic one in the relation with wellbeing. Delle Fave et al. find large cross-country differences in happiness and meaningfulness ratings in the spiritual/religious domain, and they emphasize the role of high levels of spiritual/religious meaning overall contributing to wellbeing. ${ }^{9}$ Monika Ardelt, basing her conclusions on a study of community-dwelling older adults in North Central Florida, finds that purpose in life rather than extrinsic or intrinsic religious orientation was positively associated with elders' subjective wellbeing and negatively associated with fear of death or death avoidance. In contrast, she finds that both frequency of religious activity and religious affiliation were unrelated to subjective wellbeing but positively associated with death avoidance and fear of death. Kennedy et al. develop a model where transcendent experiences affect religious commitment, which in turn influences meaning in life, and, in turn, wellbeing. They test the model based on a convenience sample of 182 people in the United States and find that the mediating influences they have identified hold, although they cannot ascertain causality. ${ }^{10}$

Both dimensions seem to matter, and that may vary according to context. Several studies find that the relationship between religion and wellbeing is weaker in countries that are more prosperous or in regions or states within such countries that are particularly prosperous. ${ }^{11}$ Other studies find an important role for religion as a coping mechanism in the face of hardship, and some highlight that religion's importance increases with age. Clark and Lelkes find that in Europe respondents who have a religious affiliation suffer lower wellbeing costs due to becoming unemployed than do those without religious affiliation, for example. In contrast, though, they find that Protestants suffer less and Catholics suffer more than the average from marital separation. Their results do not seem to be endogenous to religion, as they correspond to both attitudes and behavior. The religious are both anti-divorce and anti-job creation for the unemployed, for example, and the religious unemployed are less likely to be actively looking for work.

Deaton, in conclusions based on the Gallup World Poll, finds that the elderly and women are more likely to be religious. In addition, in most countries religious people report better health, say they have greater energy, and that they experience less pain than do those without a religious affiliation. They are more likely to be married, to have supportive friends, to report being treated with respect, to have greater confidence in the healthcare system, and they are less likely to smoke. ${ }^{12}$ Given that the GWP is cross-section data, we of course do not know the direction of causality and it may be that happier people are more likely to have better attitudes, to be religious, and to refrain from harmful behaviors.

Deaton and Stone (2013) find a religion and wellbeing "puzzle" in the United States, in which religious people report higher levels of hedonic and evaluative wellbeing, but this finding does not carry through to a comparison of more or less religious places. In the United States, religious states have lower average scores on the best possible life (bpl) question but many objective indicators, ranging from income levels to crime and murder rates, are higher in more religious states (zip codes) in the United States. Because of this clear income effect, once income is

\footnotetext{
${ }^{9}$ Delle Fave, Brdar, and Vella-Brodrick (2013).

10 The sample consisted of people who were interested in paranormal phenomena, including people who had attended talks on parapsychology, contacted a parapsychology research center, or had ordered books or materials related to paranormal phenomena. The mean age of respondents was 38 and ranged from 16 to 89 . About $35 \%$ were under age 25 and 15\% were over age 60. Women were 70\% of the sample. Kennedy and Kanthamani (1995) and Ardelt (2003).

${ }^{11}$ Deaton and Stone (2013); Diener et al (2011); Ellison (1991); Mookerjee and Beron (2005); Clark and Lelkes (2009); Lelkes (2002); and Lim and Putnam (2010).

12 Deaton (2009).
} 
controlled for in the regression, the positive effect of religiosity on wellbeing returns. Deaton and Stone (2013) find similar trends based on less fine-grained data from around the world in the GWP. Their research suggests that religion may be a coping mechanism in places where life is more adverse and beyond the control of individuals' own effort. For daily happiness, however (the same as our experienced wellbeing measure), both religious individuals and religious countries have higher levels on average. Religious Americans are also happier and more religious states in America are happier than others. ${ }^{13}$

Diener et al., in work also based on the GWP, find that nations and states around the world with difficult life circumstances (hunger and low life expectancy) are much more likely to be highly religious. In these countries religiosity was associated with higher levels of all three kinds of SWB. In contrast, in societies with more favorable circumstances, religiosity is less prevalent and the difference in wellbeing between the religious and non-religious is much smaller. ${ }^{14}$ Other studies find that religious involvement is associated with fewer depressive symptoms and less anxiety and better quality of life indicators (Huang et al); with higher morale (Koenig et al); and with higher levels of late-life wellbeing (McFadden et al). ${ }^{15}$

There is also, of course, the problem of endogeneity, in which happier people may be more likely to be religious and/or to become religious at times of adversity. Olga Popova (2010), for example, finds that religious people in the former centrally planned economies experienced lower drops in happiness during the transition to market economies, but she also finds major bias in the coefficients, due to endogeneity. As a means to correct this bias, she uses historical religious density as an instrument, and the results on religion as an insurance mechanism still hold. ${ }^{16}$

While the literature identifies a consistently positive relationship between religion and wellbeing, that relationship varies in its importance across countries and across the different dimensions of wellbeing. We attempt to probe a bit further along these lines of inquiry. We separate religious attendance and the intrinsic qualities of religion in order to explore the importance of dimensions of hedonic and evaluative wellbeing in countries around the world. We also explicitly test the role of socializing associated with religion. We also look across different religious affiliations within countries. We examine how or if the relationship varies across people with more means and capabilities (and presumably facing less adversity), looking across countries at different levels of development.

Finally, in the absence of panel data, it is difficult to know if happier people are more likely to be religious, or if religion makes people happier. The standard approach to address endogeneity issues such as this one is to use an instrumental variable, as Popova (2010) does. Yet it is difficult to find a credible instrument when both beliefs and attitudes/character traits are the integral components of the question at hand. Consequently we take a fairly novel approach and use quantile regressions to examine how the relationship varies at different points of the wellbeing distribution. Binder and Coad (2011) find that the importance to wellbeing of factors such as education and income diminishes at higher levels of the wellbeing distribution. While education, for example, is positive for wellbeing in general, it is negatively correlated with wellbeing at the top of the distribution. Graham and Nikolova (2013), in research based on the Gallup World Poll, find that the importance of a number of measures of agency decreases from the $25^{\text {th }}$ percent quantile (i.e., the unhappiest quantile) to the $90^{\text {th }}$ percent quantile (i.e., the

\footnotetext{
${ }^{13}$ Deaton and Stone (2013).

${ }^{14}$ Diener et al. (2011).

${ }^{15}$ Huang, Hsu, and Chen (2012); Koenig, Kvale, and Ferrel (1998); and McFadden (1995).

${ }^{16}$ Popova (2010).
} 
happiest quantile). These include: the absence of a health problem, hard work, income, education, being employed part-time and not wanting full-time employment; and being unemployed. All these variables are least important to the wellbeing of the happiest respondents (perhaps because they are happy regardless of objective conditions). On the other hand the researchers find that learning, in contrast to the other agency variables, is very important for the happiest people, with causality likely running in both directions.

In this paper we will explore the extent to which the positive relationship between religion and wellbeing is driven by the upper tail of the wellbeing distribution, based on quantile regressions. In doing so, we examine the relationship between happiness and religion from a conditional distribution vantage point and ask, for example, whether the happiest people are happy regardless of religion (and/or other variables such as income). While we cannot fully resolve the standard endogeneity-causality issue, our results should provide some insight into it.

\section{Data and models}

We rely on the Gallup World Poll (GWP), for the years 2005-2011, for base-line data for our empirical analysis. The GWP is an annual survey run by the Gallup Organization that has covered roughly 160 countries worldwide since 2005. It has nationally representative coverage in most countries, ranging from more than 4,000 household interviews in China every year to 500 households in Puerto Rico, and up to 6,000 households in India in select years. Interviews are face to face in countries where telephone coverage is limited and by telephone where it is universal (primarily the OECD countries). We do not apply weights to the data, as the GWP has a unified sampling approach, and because weighting subjective wellbeing responses assumes that they are identical across similar people in similar places, as income or other objective data might be. We do not feel that is a realistic assumption.

Our income variable is logged household data, with controls for household size in our regressions. The GWP records respondents' annual household income in local currencies and converts them into comparable international dollar values (using the 2005 household PPP ratio from the World Bank). However, some respondents indicate their income using pre-determined brackets rather than providing specific amounts. For these observations, household income is imputed by using the midpoint of each bracket and dividing it by the PPP ratio. The respondents (both those who give an exact income amount and those who choose a bracket) are then placed into the appropriate income quintile or decile category for their country. While the approach is not free of error, most income data for poor countries is based on survey responses, introducing a similar margin of error. The Gallup Poll data, including its income components, has been widely used by economists in the past few years. ${ }^{17}$

In addition to covering the usual socio-demographic indicators, the Gallup Poll has more than a thousand questions, on topics ranging from reported wellbeing to attitudes to corruption, confidence in institutions, civic engagement, religiosity, and perceptions of economic performance - both at an individual level and at a national level. (For summary statistics on the key variables there-in, see Appendix.) We also rely on the World Bank's World Development Indicators for macroeconomic data and country income classifications in one of our models. ${ }^{18}$

\footnotetext{
17 The approach has been vetted among a range of academic advisors to the Poll, who include Angus Deaton and Daniel Kahneman. As of 2013, the Poll has begun to make its income data more detailed and comparable to that taken from household surveys, but that is still a work in progress.

${ }^{18} \mathrm{http}$ //databank.worldbank.org/data/views/variableSelection/selectvariables.aspx?source=world-developmentindicators
} 
Our measures of wellbeing are happy yesterday and the Cantril ladder of life question. Happy yesterday is one among a few possible hedonic questions that are intended to capture positive affect and experience. Other questions, such as those related to stress and anger, capture negative hedonic experience. Psychologists stress that positive and negative affect are not one continuum and must be measured separately. In this instance we are more interested in the positive dimension, although we have also worked with the negative dimension in related work. ${ }^{19}$ The yesterday questions, while much simpler than more detailed metrics of hedonic wellbeing, such as daily reconstruction methods, track remarkably well with the more detailed questions and are reliable substitutes in large-scale surveys..$^{20}$ The Cantril ladder of life question, which asks respondents to rank their lives compared to the best possible life they can imagine on a ten-step ladder, is widely used as a measure of life evaluation. It is important to note, however, that by referencing the best possible life, it is more framed than are open-ended life satisfaction questions, and correlates more closely with income within and across countries than do the latter. 21

Because the scale for the explained variables is ordinal and not cardinal in nature, we use (as is the standard practice) an ordered logit or logit specification in our regressions. The coefficients on ordered logits can, most strictly, be interpreted as odds ratios or the difference in the probability that respondents are in one versus the next highest or lowest response category (therefore there is no intercept). In practice, the dependent variables in wellbeing regressions whether life satisfaction or ladder of life - are more than just an ordinal ranking of preferences, as the reference points at each end of the spectrum offer respondents choices that run from very bad to very good or worst to best. As a result, the variables "mimic" a cardinal metric, and it is increasingly common practice to use standard OLS equations on the same data and equations, because the coefficients and statistical significance are essentially identical, thus allowing for comparison across the coefficients.

\subsection{Model 1}

We began with a base-line model in which we had hedonic or evaluative wellbeing as the dependent variable, with happy yesterday and the Cantril ladder question, respectively. We then include, on the right side, two variables designed to capture the different elements of religion: how important religion is to respondents' lives (religion important) and how often people attend religious services (religious service). We include the usual socio-economic and demographic controls - income, age, age ${ }^{2}$, gender, employment status, health status, among others - as well as country dummies for the roughly 160 countries polled in the years for which Gallup has data.

\footnotetext{
${ }^{19}$ Our results using stress and anger are remarkably similar to those based on happy yesterday, showing the opposite signs, for the most part, as one would expect, although at times anger tracks differently from stress. Results are available from the authors on request; the relationship between religion and anger and stress were also the focus of Crown's Master's thesis for the University of Nevada at Las Vegas, which she defended in November 2013.

${ }^{20}$ One of the authors was a member of a National Academy of Sciences panel tasked with recommending which hedonic wellbeing metrics were reliable enough to be included in U.S. national statistics, and, as such, was exposed to detailed discussions on the topic with some of the psychologists who developed the metrics. Detail is in the report. Arthur Stone and Chris Mackie, eds. (2013), Subjective Well-Being: Measuring Happiness, Suffering, and Other Dimensions of Experience (Washington, D.C.: The National Academies Press).

${ }^{21}$ See Carol Graham, Soumya Chattopadyay, and Mario Picon, "The Easterlin and Other Paradoxes: Why Both Sides of the Debate May be Correct" in Ed Diener, John Helliwell, and Daniel Kahneman, eds. (2010), International Differences in Well-Being (Oxford: Oxford University Press).
} 
Because religious affiliation is not something that is likely to vary in very short time periods, we do not include time dummies and instead treat our 5-year sample as a pooled cross section. (As a robustness check, we ran our base model with year dummies included and our results are essentially unchanged.)

We also added the primary religions for which we have respondents with sufficient observations in the survey: Christian, Catholic, Protestant, Islam, Shiite, Sunni, Druze, Hindu, Buddhist, Indigenous, Judaism, and Non-religious (the left-out category in all of the regressions). The distribution of religious density across countries is in Table 1, which lists religious frequency in responses per country in the Gallup Poll.

Table 1. Respondent's religious affiliation

\begin{tabular}{lrrr}
\hline Religion & \multicolumn{1}{c}{ Yes } & \multicolumn{1}{c}{ No } & Percent \\
\hline Christian - Not Specified & 56,261 & 820,313 & $6 \%$ \\
Catholic Christian & 208,319 & 668,255 & $24 \%$ \\
Protestant Christian & 117,467 & 759,107 & $13 \%$ \\
Orthodox Christian & 70,717 & 805,857 & $8 \%$ \\
Muslim - Not Specified & 185,140 & 691,434 & $21 \%$ \\
Muslim - Shiite & 16,462 & 860,112 & $2 \%$ \\
Muslim - Sunni & 67,685 & 808,889 & $8 \%$ \\
Druze & 918 & 875,656 & $0 \%$ \\
Hindu & 34,797 & 841,777 & $4 \%$ \\
Buddhist & 45,273 & 831,301 & $5 \%$ \\
Indigenous & 2,859 & 873,715 & $0 \%$ \\
Jew & 6,294 & 870,280 & $1 \%$ \\
Non-Religious & 52,659 & 823,915 & $6 \%$ \\
Other Religion & 11,723 & 864,851 & $1 \%$ \\
\hline Total & 876,574 & $11,395,462$ & $100 \%$ \\
\hline Source: Gallup Wor
\end{tabular}

Source: Gallup World Poll (2005-2011)

Note: Individuals may report not belonging to a specific religion more than once thus resulting in a larger sample of no responses than other specifications, and thus the sample size may change with different specifications.

Self-reported wellbeing $=\alpha^{\prime} *$ individual level means and capabilities $+\beta^{\prime} *$ individual level variables $+\gamma^{\prime *}$ household level variables $+\phi^{*}$ person specific religion variables $+\mathrm{Q}^{\prime *}$ religion is important $+\delta^{\prime *}$ religious service attendance + country dummies + error term

Where:

- Self-reported wellbeing is an individual response to either (1) "Did you experience happiness yesterday or (2) Cantril ladder of life question, "How does your life compare to the best possible life on a scale of 1 to 10 ?"

- $\quad \alpha^{\prime}, \beta^{\prime}, \gamma^{\prime}, \phi^{\prime}, \delta^{\prime}, Q^{\prime}$ are coefficient vectors; the error term is an individual-level residual

- Means and capabilities refer to individual-level descriptors including income and education

- Individual-level variables include gender, age, age-squared, and marital status 
- Household-level variables are person specific and include household size as well as population density (urban or rural)

- Religion variables are individual specific dummies referring to self-proclaimed religious identity

- Religion important is a response to whether religion is important or not

- Religious service is a response to whether an individual attended a religious service in the last week outside a wedding or other ceremony

Country dummies for all 160 countries covered by the Gallup Poll are included. Most countries are surveyed every year; a few were added in later years.

\subsection{Model 2}

We next added our socializing variable to the equations, to see first, if our results varied once we controlled for how much people socialized, and second, if the effects of socializing were mediated by being religious or not. We created dummy variables based on how much people socialized. The question in the Gallup poll is, "How many hours do you spend with friends and family each day," with possible responses being between zero and four hours, between five and nine hours, between ten and fourteen hours and over 15 hours. Social 1 was the least amount of hours, Social 3 was between ten and fourteen hours, and Social 4 was over 15 hours. Social 1 is the left out category in most of the regressions, as Social 4 seems to be an outlier category that is not a reliable comparator. ${ }^{22}$ We then created an inter-action variable with the frequency of religious service attendance and frequency of socializing.

Self-reported wellbeing $=\alpha^{\prime *}$ individual level means and capabilities $+\beta^{\prime} *$ individual level variables $+\gamma^{*}$ household level variables $+\phi^{*}$ person specific religion variables $+\mathrm{Q}^{\prime *}$ religion is important $+\delta^{\prime *}$ religious service attendance + country dummies + social dummies and interactions + error term

Where:

- Social dummies represent an individual-level response to how much time one spends with friends and family in a 24-hour period

- Interaction terms between religious service attendance and frequency of socialization are also included

\subsection{Model 3}

We then expanded the model to see if our results varied depending on whether respondents were in a country which was predominantly Christian or not, splitting the sample into those countries where the majority of the respondents (more than $50 \%$ of respondents in our data by country) were or were not Christian, and, as before, include country but not year dummies. This is, therefore, the same as our base-line model (above) but with the sample split into two. (The leftout category is again non-religious).

Self-reported wellbeing $=\alpha^{\prime *}$ individual level means and capabilities $+\beta^{\prime} *$ individual level variables $+\gamma^{*}$ household level variables $+\phi^{*}$ person specific religion variables $+\mathrm{Q}^{\prime *}$ religion is important $+\delta^{\prime *}$ religious service attendance + country dummies + social dummies and interactions + error term; where Christian majority $==0$ or $==1$

\footnotetext{
${ }^{22}$ Socializing for more than 15 hours seems an unrealistic amount. Some of those respondents who choose this category may be involved in domestic labor, for example. We thank an anonymous reader for making this point.
} 
Where:

- If an individual resides in a country where the majority of the population (more than fifty percent) identifies as a form of Christian, Christian majority is one (1), otherwise it is zero (0)

\subsection{Model 4}

To test whether the relationship between religion and our two wellbeing dimensions changes as countries (and people within them) grow more prosperous, we split our sample into regions of different levels of development, based on the World Bank's World Development Indicators (WDI) and explored whether the results across the two wellbeing dimensions differ in countries that are very poor versus those that are very prosperous. We include country dummies in addition to the broader WDI income categories.

Self-reported wellbeing $=\alpha^{\prime} *$ individual level means and capabilities $+\beta^{\prime} *$ individual level variables $+\gamma^{*}$ household level variables $+\phi^{*}$ person specific religion variables $+\mathrm{Q}^{\prime *}$ religion is important $+\delta^{\prime *}$ religious service attendance + country dummies + social dummies and interactions + error term; where cincwdi $==1,==2$, or $==3$

Where:

- Cincwdi refers to country-level income. One (1) refers to low-income countries, while two

(2) refers to middle-income countries and three (3) refers to high-income countries

\subsection{Model 5}

Finally, we explored how or if the relationship between religion and wellbeing varied depending where respondents were in the wellbeing distribution. Following an approach we utilized in Graham and Nikolova (2013), also with Gallup World Poll data, and that was utilized in earlier work by Binder and Coad (2011) and Koener and Bassett (1978), we analyzed our sample at each quantile of the wellbeing distribution. While standard regressions describe the conditional mean, quantile regressions allow us to explore the entire conditional distribution by analyzing the effects of the covariates at different points of the wellbeing distribution. Rather than splitting the sample into segments based on values of the dependent variable, quantile regressions weigh data points depending on whether they are above or below the best fit line.

Quantile regressions have several advantages. Understanding what is happening at the extremes of the distribution demonstrates that some variables are not equally relevant for the happiest and unhappiest individuals. As such, some policy interventions that have a positive effect on the majority can also cause larger gains or losses for a minority. And methodologically, estimating means across heterogeneous populations may fail to identify effects on some cohorts. Quantile regressions assume that the error terms are not identically distributed at all points of the conditional distribution, but rather that the slope parameters differ along the quantiles, as such allowing for individual heterogeneity (Binder and Coad, 2011). ${ }^{23}$

Our quantile regression model follows that of Koenker and Bassett (1978) and Binder and Coad (2011):

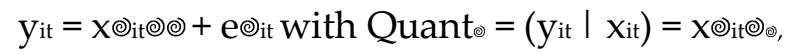

\footnotetext{
${ }^{23}$ Binder, M., \& Coad, A. (2011). From Average Joe's happiness to Miserable Jane and Cheerful John: Using Quantile Regressions to Analyze the Full Subjective Well-being Distribution. Journal of Economic Behavior E Organization, 79(3), 275-290.
} 
Where:

- $y_{i t}$ is subjective wellbeing (BPL)

- $x @$ is a vector of covariates

- $\quad$ is the vector of parameters to be estimated

- $\quad$ and $e$ is the stochastic error term

- Quant $_{\odot}=\left(\mathrm{y}_{\mathrm{it}} \mid \mathrm{x}_{\mathrm{it}}\right)$ is the th conditional quantile (where $0<0<1$ ) of wellbeing (y) given the covariates and $\checkmark$ solves the following minimization problem:

$$
\left.\min _{\beta} \frac{1}{n}\left\{\sum_{i, t: y \geq x_{i t}^{\prime} \beta} \theta_{\mid} y_{i t}-x_{i t}^{\prime} \beta_{\mid}+\sum_{i, t: y \geq x_{i t}^{\prime} \beta}(1-\theta)_{\mid} y_{i t}-x_{i t}^{\prime} \beta_{\mid}\right)\right\}=\min _{\beta} \frac{1}{n} \sum_{i=1}^{n} \rho_{\theta}\left(u_{\theta i t}\right)
$$

where ๑๑ (.) is:

$$
\rho_{\theta}\left(u_{\theta i t}\right)=\left\{\begin{array}{c}
\theta u_{\theta i t} \text { if } u_{\theta i t} \geq 0 \\
(\theta-1) u_{\theta i t} \text { if } u_{\theta i t}<0
\end{array}\right\}
$$

The equations are operationalized by the statistical programming method in Stata's sqreg command. We also used bootstrapped standard errors (20 iterations). ${ }^{24}$ As in the case of most of the above models, we include country dummies in our specification and the left out religious category is Christian.

\section{Results}

We cannot make exact comparisons across the coefficients in these separate equations, of course, as the dependent variables are on different scales (0-1 and 0-10), and the logit and ordered logit specifications are categorical and not continuous. This makes estimating standardized coefficients complex at best. Thus we are not making direct comparisons of the values of the coefficients across the equations in our analysis, and simply focus primarily on the signs on the coefficients and the orders of magnitude of the differences. These are very much in keeping with our hypotheses, as well as earlier work exploring differences in wellbeing dimensions.

\subsection{Indicators of individual means and capabilities}

The coefficients on objective indicators, such as income, education, and living in an urban area, are an order of magnitude larger for the bpl variable, our evaluative wellbeing measure, than they are for the happiness yesterday variable, our hedonic measure. Marriage has a much stronger coefficient in the happiness regressions than it does in the bpl regressions. Our earlier research, as well as that of others, finds a stronger relationship between income and other proxies for a higher standard of living and evaluative wellbeing than hedonic wellbeing. While extreme deprivation is bad for both dimensions of wellbeing, after a certain point more income is not likely to improve affective states (such as smiling more or being angry less), but it surely gives individuals more opportunities and choices to lead the kinds of lives they want to lead. Of all the evaluative questions, people's means, capabilities, and opportunities seem to be best reflected in the best possible life question (as opposed to general happiness or life satisfaction, for example). ${ }^{25}$

\footnotetext{
${ }^{24}$ For further discussion of the quantile regression method, see Buchinsky, M. (1998), "Recent Advances in Quantile Regression Models: A Practical Guideline for Empirical Research", The Journal of Human Resources, 33(1), 88-126. Cade, B. S., \& Noon, B. R. (2003), "A gentle introduction to quantile regression for ecologists", Frontiers in Ecology and the Environment, 1(8), 412-420; and Koenker, R., \& Hallock, K. F. (2001), "Quantile Regression", The Journal of Economic Perspectives, 15(4), 143-156.

${ }^{25}$ Carol Graham, Soumya Chattopadhyay, and Mario Picon (2010), “The Easterlin and Other Paradoxes: Why Both Sides of the Debate Might be Correct" in Ed Diener, John Helliwell, and Daniel Kahneman, eds., International Differences in Well-Being (Oxford: Oxford University Press); Daniel Kahneman and Angus Deaton (2010), “High income improves
} 


\subsection{Indicators of religion}

Both of our religion variables - reporting that religion is an important part of one's daily life and attending religious services - are positively and significantly correlated with happy yesterday. Attending religious services also correlates positively with BPL, but religion is important is insignificant. While the variable "attending religious services" holds its positive association across the wellbeing dimensions, the spiritual or purposeful aspect of religiosity does not hold for evaluative wellbeing. Hedonic wellbeing captures shorter daily experiences, in which religion seems to play a consistent role. Evaluative wellbeing captures life as a whole, both in terms of the life cycle and of purpose or meaning in life, and the determinants of the latter may vary a great deal depending on people's means and capabilities, among other things, and thus the role of religion may vary more (see Table 2).

Table 2. Regression analysis of evaluative and hedonic wellbeing

\begin{tabular}{lcc}
\hline & Happy & BPL \\
& $(\mathbf{1})$ & $\mathbf{( 2 )}$ \\
\hline Religion Important & $0.147^{* * *}$ & 0.007 \\
& $(0.014)$ & $(0.01)$ \\
Religious Service & $0.168^{* * *}$ & $0.101^{* * *}$ \\
Urban & $(0.011)$ & $(0.008)$ \\
& $0.036^{* * *}$ & $0.151^{* * *}$ \\
Household Size & $(0.01)$ & $(0.007)$ \\
Ln(Household income) & 0.004 & -0.001 \\
& $(0.003)$ & $(0.002)$ \\
Gender & $0.171^{* * *}$ & $0.356^{* * *}$ \\
Age (in years) & $(0.004)$ & $(0.004)$ \\
& 0.007 & $0.058^{* * *}$ \\
Age-Squared & $(0.009)$ & $(0.007)$ \\
& $-0.043^{* * *}$ & $-0.034^{* * *}$ \\
Marital Status & $(0.001)$ & $(0.001)$ \\
& $0.0003^{* * *}$ & $0.00026^{* * *}$ \\
& $(0.00002)$ & $(0.00001)$ \\
& $0.267^{* * *}$ & $0.126^{* * *}$ \\
& $(0.01)$ & $(0.008)$
\end{tabular}

Table 2 (cont.). Regression analysis of evaluative and hedonic wellbeing

\begin{tabular}{lcc}
\hline & Happy & BPL \\
\hline Education & $\mathbf{( 1 )}$ & $\mathbf{( 2 )}$ \\
\hline \multirow{2}{*}{ Christian } & $0.181^{* * *}$ & $0.404^{* * *}$ \\
& $(0.015)$ & $(0.01)$ \\
Catholic Christian & $0.125^{* * *}$ & $0.12^{* * *}$ \\
& $(0.038)$ & $(0.028)$ \\
Protestant Christian & $0.152^{* * *}$ & 0.019 \\
& $(0.028)$ & $(0.02)$ \\
& $0.203^{* * *}$ & $0.049^{* *}$
\end{tabular}

evaluation of life but not emotional well-being", Proceedings of the National Academy of Sciences, 107, 16489-16493; and Graham and Nikolova (2013). 
Orthodox Christian

Muslim

Shiite Muslim

Sunni Muslim

Druze

Hindu

Buddhist

Indigenous

Jew

Constant

Number of Observations

Pseudo R-squared

Country Dummies

$$
\text { (0.03) }
$$

$0.143^{* * *}$

$0.169^{* * *}$

(0.021)

(0.033)

$-0.111^{* * *}$

$0.168^{* * *}$

(0.026)

0.007

(0.024)

(0.047)

$-0.11^{* * *}$

$0.123^{* * *}$

(0.036)

(0.037)

$-0.058^{* *}$

0.179

(0.027)

(0.135)

$0.196^{*}$

$0.194^{* * *}$

(0.112)

(0.051)

0.048

$0.093^{* *}$

(0.035)

(0.043)

$-0.014$

0.044

(0.099)

$-0.066$

$0.408^{* * *}$

(0.077)

(0.101)

$0.315^{* * *}$

$1.165^{\text {*** }}$

(0.069)

(0.105)

261,324

0.0843

294,620

yes

0.0763

Source: Gallup World Poll (2005-2011)

Notes: All regressions use robust standard errors and country dummies. We treat the sample as a pooled cross section and therefore do not include year dummies. BPL measures the respondent's assessment of her current life relative to her best possible life. Happy is a binary variable coded 1 if the respondent experienced happiness the day before and 0 otherwise. Household income is log-transformed and is in international dollars (ID), which allows comparisons across countries and time. Model (1) is estimated using logit while Model (2) is estimated using ordered logit.

$$
{ }^{* * *} \mathrm{p}<0.01,{ }^{* *} \mathrm{p}<0.05,{ }^{*} \mathrm{p}<0.10
$$

The distribution of respondents of different religions across our sample is in Table 1 (above). When we look at the coefficients on the different religions (with non-religious being the omitted category), we find that, compared to the non-religious, most affiliations have higher happy yesterday scores, with the exception of Druze and indigenous respondents. The patterns on bpl are less consistent. Protestants, Christians, and Jews have higher bpl scores than the nonreligious, while orthodox Christians, Shiites, Sunnis, and Buddhists have lower ones ${ }^{26}$ (see Table 2).

\subsection{Indicators of Sociability}

When we include our social variables, and our interaction terms for levels of sociability and attending religious services, we find that first, both happiness and bpl levels (compared to the least social category) increase for social 2 (5-9 hours) and social 3 (10-14 hours), and then drop

\footnotetext{
${ }^{26} 90.55 \%$ of Jewish respondents are in Israel and the next highest percentage (2\%) is in the U.S. See Table 1 (above) on the distribution of religions across the sample.
} 
slightly for the most social category (over 15 hours!) (see Table 3). It is likely that this very high level of socialization enhances daily experience but is not as conducive to focusing on other life goals and achievements.

Table 3. Regression analysis of evaluative and hedonic wellbeing including social indicators

\begin{tabular}{|c|c|c|c|c|c|c|c|c|}
\hline & $\begin{array}{c}\text { Happy } \\
\text { (1) }\end{array}$ & $\begin{array}{l}\text { BPL } \\
(2)\end{array}$ & $\begin{array}{c}\text { Happy } \\
\text { (3) }\end{array}$ & $\begin{array}{l}\text { BPL } \\
(4)\end{array}$ & $\begin{array}{c}\text { Happy } \\
\text { (5) }\end{array}$ & $\begin{array}{l}\text { BPL } \\
(6)\end{array}$ & $\begin{array}{c}\text { Happy } \\
\text { (7) }\end{array}$ & $\begin{array}{l}\text { BPL } \\
(8)\end{array}$ \\
\hline Religion & $0.098^{* * *}$ & -0.004 & $0.098^{* * *}$ & -0.004 & $0.1^{* * *}$ & -0.003 & $0.1^{* * *}$ & -0.003 \\
\hline Important & $(0.025)$ & $(0.018)$ & $(0.025)$ & $(0.018)$ & $(0.025)$ & $(0.018)$ & $(0.025)$ & $(0.018)$ \\
\hline Religious & $0.192^{* * *}$ & $0.129^{* * *}$ & $0.192^{* * *}$ & $0.129^{* * *}$ & -0.028 & $0.137^{* * *}$ & $0.307^{* * *}$ & $0.172^{* * *}$ \\
\hline Service & (0.019) & $(0.014)$ & (0.019) & $(0.014)$ & $(0.066)$ & $(0.047)$ & $(0.024)$ & $(0.017)$ \\
\hline Urban & $\begin{array}{l}-0.005 \\
(0.019)\end{array}$ & $\begin{array}{l}0.141^{* * *} \\
(0.013)\end{array}$ & $\begin{array}{l}-0.005 \\
(0.019)\end{array}$ & $\begin{array}{l}0.141^{* * *} \\
(0.013)\end{array}$ & $\begin{array}{l}-0.006 \\
(0.019)\end{array}$ & $\begin{array}{l}0.141^{* * *} \\
(0.013)\end{array}$ & $\begin{array}{l}-0.006 \\
(0.019)\end{array}$ & $\begin{array}{l}0.141^{* * *} \\
(0.013)\end{array}$ \\
\hline $\begin{array}{l}\text { Household } \\
\text { Size }\end{array}$ & $\begin{array}{l}-0.004 \\
(0.005)\end{array}$ & $\begin{array}{l}-0.008^{* *} \\
(0.003)\end{array}$ & $\begin{array}{l}-0.004 \\
(0.005)\end{array}$ & $\begin{array}{l}-0.008^{* *} \\
(0.003)\end{array}$ & $\begin{array}{l}-0.004 \\
(0.005)\end{array}$ & $\begin{array}{l}-0.008^{* *} \\
(0.003)\end{array}$ & $\begin{array}{l}-0.004 \\
(0.005)\end{array}$ & $\begin{array}{l}-0.008^{* *} \\
(0.003)\end{array}$ \\
\hline $\begin{array}{l}\text { Ln(House- } \\
\text { hold income) }\end{array}$ & $\begin{array}{l}0.172^{* * *} \\
(0.007)\end{array}$ & $\begin{array}{l}0.379^{* * *} \\
(0.006)\end{array}$ & $\begin{array}{l}0.172^{* * *} \\
(0.007)\end{array}$ & $\begin{array}{l}0.379^{* * *} \\
(0.006)\end{array}$ & $\begin{array}{l}0.172^{* * *} \\
(0.007)\end{array}$ & $\begin{array}{l}0.379^{* * *} \\
(0.006)\end{array}$ & $\begin{array}{l}0.172^{* * *} \\
(0.007)\end{array}$ & $\begin{array}{l}0.379^{* * *} \\
(0.006)\end{array}$ \\
\hline Gender & $\begin{array}{l}-0.017 \\
(0.017)\end{array}$ & $\begin{array}{l}0.058^{* * *} \\
(0.012)\end{array}$ & $\begin{array}{l}-0.017 \\
(0.017)\end{array}$ & $\begin{array}{l}0.058^{* * *} \\
(0.012)\end{array}$ & $\begin{array}{l}-0.015 \\
(0.017)\end{array}$ & $\begin{array}{l}0.059^{* * *} \\
(0.012)\end{array}$ & $\begin{array}{l}-0.015 \\
(0.017)\end{array}$ & $\begin{array}{l}0.059^{* * *} \\
(0.012)\end{array}$ \\
\hline $\begin{array}{l}\text { Age (in } \\
\text { years) }\end{array}$ & $\begin{array}{l}-0.046^{* * *} \\
(0.003)\end{array}$ & $\begin{array}{l}-0.031^{* * *} \\
(0.002)\end{array}$ & $\begin{array}{l}-0.046^{* * *} \\
(0.003)\end{array}$ & $\begin{array}{l}-0.031^{* * *} \\
(0.002)\end{array}$ & $\begin{array}{l}-0.046^{* * *} \\
(0.003)\end{array}$ & $\begin{array}{l}-0.031^{* * *} \\
(0.002)\end{array}$ & $\begin{array}{l}-0.046^{* * *} \\
(0.003)\end{array}$ & $\begin{array}{l}-0.031^{* * *} \\
(0.002)\end{array}$ \\
\hline Age-Squared & $\begin{array}{l}0.00033^{* * *} \\
(0.00003)\end{array}$ & $\begin{array}{l}0.00025^{* * *} \\
(0.00002)\end{array}$ & $\begin{array}{l}0.00033^{* * *} \\
(0.00003)\end{array}$ & $\begin{array}{l}0.00025^{* * *} \\
(0.00002)\end{array}$ & $\begin{array}{l}0.00033^{* * *} \\
(0.00003)\end{array}$ & $\begin{array}{l}0.00025^{* * *} \\
(0.00002)\end{array}$ & $\begin{array}{l}0.00033^{* * *} \\
(0.00003)\end{array}$ & $\begin{array}{l}0.00025^{* * *} \\
(0.00002)\end{array}$ \\
\hline $\begin{array}{l}\text { Marital } \\
\text { Status }\end{array}$ & $\begin{array}{l}0.256^{* * *} \\
(0.019)\end{array}$ & $\begin{array}{l}0.126^{* * *} \\
(0.014)\end{array}$ & $\begin{array}{l}0.256^{* * *} \\
(0.019)\end{array}$ & $\begin{array}{l}0.126^{* * *} \\
(0.014)\end{array}$ & $\begin{array}{l}0.253^{* * *} \\
(0.019)\end{array}$ & $\begin{array}{l}0.125^{* * *} \\
(0.014)\end{array}$ & $\begin{array}{l}0.253^{* * *} \\
(0.019)\end{array}$ & $\begin{array}{l}0.125^{* * *} \\
(0.014)\end{array}$ \\
\hline Education & $\begin{array}{l}0.183^{* * *} \\
(0.027)\end{array}$ & $\begin{array}{l}0.443^{* * *} \\
(0.018)\end{array}$ & $\begin{array}{l}0.183^{* * *} \\
(0.027)\end{array}$ & $\begin{array}{l}0.443^{* * *} \\
(0.018)\end{array}$ & $\begin{array}{l}0.184^{* * *} \\
(0.027)\end{array}$ & $\begin{array}{l}0.443^{* * *} \\
(0.018)\end{array}$ & $\begin{array}{l}0.184^{* * *} \\
(0.027)\end{array}$ & $\begin{array}{l}0.443^{* * *} \\
(0.018)\end{array}$ \\
\hline \multicolumn{9}{|c|}{ Religion Categories (Ref. Group: Non-religious) } \\
\hline $\begin{array}{l}\text { Other } \\
\text { Religion }\end{array}$ & $\begin{array}{c}0.102 \\
(0.104)\end{array}$ & $\begin{array}{l}-0.08 \\
(0.065)\end{array}$ & $\begin{array}{c}0.102 \\
(0.104)\end{array}$ & $\begin{array}{l}-0.08 \\
(0.065)\end{array}$ & $\begin{array}{c}0.103 \\
(0.105)\end{array}$ & $\begin{array}{l}-0.079 \\
(0.065)\end{array}$ & $\begin{array}{c}0.103 \\
(0.105)\end{array}$ & $\begin{array}{l}-0.079 \\
(0.065)\end{array}$ \\
\hline Christian & $\begin{array}{l}0.225^{* * *} \\
(0.07)\end{array}$ & $\begin{array}{c}0.077 \\
(0.05)\end{array}$ & $\begin{array}{l}0.225^{* * *} \\
(0.07)\end{array}$ & $\begin{array}{c}0.077 \\
(0.05)\end{array}$ & $\begin{array}{l}0.228^{* * *} \\
(0.07)\end{array}$ & $\begin{array}{c}0.079 \\
(0.05)\end{array}$ & $\begin{array}{l}0.228^{* * *} \\
(0.07)\end{array}$ & $\begin{array}{c}0.079 \\
(0.05)\end{array}$ \\
\hline $\begin{array}{l}\text { Catholic } \\
\text { Christian }\end{array}$ & $\begin{array}{l}0.219^{* * *} \\
(0.049)\end{array}$ & $\begin{array}{c}0.028 \\
(0.034)\end{array}$ & $\begin{array}{l}0.219^{* * *} \\
(0.049)\end{array}$ & $\begin{array}{c}0.028 \\
(0.034)\end{array}$ & $\begin{array}{l}0.225^{* * *} \\
(0.049)\end{array}$ & $\begin{array}{c}0.03 \\
(0.034)\end{array}$ & $\begin{array}{l}0.225^{* * *} \\
(0.049)\end{array}$ & $\begin{array}{c}0.03 \\
(0.034)\end{array}$ \\
\hline $\begin{array}{c}\text { Protestant } \\
\text { Christian }\end{array}$ & $\begin{array}{l}0.27^{* * *} \\
(0.052)\end{array}$ & $\begin{array}{l}0.098^{* * *} \\
(0.036)\end{array}$ & $\begin{array}{c}0.27^{* * *} \\
(0.052)\end{array}$ & $\begin{array}{l}0.098^{* * *} \\
(0.036)\end{array}$ & $\begin{array}{l}0.277^{* * *} \\
(0.052)\end{array}$ & $\begin{array}{c}0.1^{* * *} \\
(0.036)\end{array}$ & $\begin{array}{l}0.277^{* * *} \\
(0.052)\end{array}$ & $\begin{array}{l}0.1^{* * *} \\
(0.036)\end{array}$ \\
\hline $\begin{array}{l}\text { Orthodox } \\
\text { Christian }\end{array}$ & $\begin{array}{l}0.175^{* *} \\
(0.068)\end{array}$ & $\begin{array}{l}-0.051 \\
(0.051)\end{array}$ & $\begin{array}{l}0.175^{* *} \\
(0.068)\end{array}$ & $\begin{array}{l}-0.051 \\
(0.051)\end{array}$ & $\begin{array}{l}0.18^{* * *} \\
(0.068)\end{array}$ & $\begin{array}{l}-0.049 \\
(0.051)\end{array}$ & $\begin{array}{l}0.18^{* * *} \\
(0.068)\end{array}$ & $\begin{array}{l}-0.049 \\
(0.051)\end{array}$ \\
\hline Muslim & $\begin{array}{l}0.214^{* * *} \\
(0.06)\end{array}$ & $\begin{array}{c}0.002 \\
(0.042)\end{array}$ & $\begin{array}{l}0.214^{* * *} \\
(0.06)\end{array}$ & $\begin{array}{c}0.002 \\
(0.042)\end{array}$ & $\begin{array}{l}0.224^{* * *} \\
(0.06)\end{array}$ & $\begin{array}{c}0.006 \\
(0.042)\end{array}$ & $\begin{array}{l}0.224^{* * *} \\
(0.06)\end{array}$ & $\begin{array}{c}0.006 \\
(0.042)\end{array}$ \\
\hline $\begin{array}{l}\text { Shiite } \\
\text { Muslim }\end{array}$ & $\begin{array}{l}0.29^{* * *} \\
(0.082)\end{array}$ & $\begin{array}{l}-0.143^{* *} \\
(0.062)\end{array}$ & $\begin{array}{l}0.29^{* * *} \\
(0.082)\end{array}$ & $\begin{array}{l}-0.143^{* *} \\
(0.062)\end{array}$ & $\begin{array}{l}0.307^{* * *} \\
(0.083)\end{array}$ & $\begin{array}{l}-0.137^{* *} \\
(0.062)\end{array}$ & $\begin{array}{l}0.307^{* * *} \\
(0.083)\end{array}$ & $\begin{array}{l}-0.137^{* *} \\
(0.062)\end{array}$ \\
\hline
\end{tabular}

Table 3 (cont.). Regression analysis of evaluative and hedonic wellbeing including social indicators

\begin{tabular}{|c|c|c|c|c|c|c|c|c|}
\hline & $\begin{array}{c}\text { Happy } \\
\text { (1) }\end{array}$ & $\begin{array}{c}\text { BPL } \\
(2) \\
\end{array}$ & $\begin{array}{c}\text { Happy } \\
(3)\end{array}$ & $\begin{array}{l}\text { BPL } \\
(4) \\
\end{array}$ & $\begin{array}{c}\text { Happy } \\
\text { (5) }\end{array}$ & $\begin{array}{c}\text { BPL } \\
(6) \\
\end{array}$ & $\begin{array}{c}\text { Happy } \\
(7)\end{array}$ & $\begin{array}{l}\text { BPL } \\
(8) \\
\end{array}$ \\
\hline Sunni & $0.228^{* * *}$ & -0.04 & $0.228^{* * *}$ & -0.04 & $0.235^{* * *}$ & -0.037 & $0.235^{* * *}$ & -0.037 \\
\hline Muslim & $(0.07)$ & $(0.05)$ & $(0.07)$ & $(0.05)$ & $(0.07)$ & $(0.05)$ & $(0.07)$ & $(0.05)$ \\
\hline \multirow[t]{2}{*}{ Druze } & 0.214 & -0.154 & 0.214 & -0.154 & 0.241 & -0.146 & 0.241 & -0.146 \\
\hline & $(0.232)$ & (0.195) & $(0.232)$ & (0.195) & $(0.232)$ & (0.195) & $(0.232)$ & $(0.195)$ \\
\hline Hindu & $0.195^{* *}$ & -0.014 & $0.195^{* *}$ & -0.014 & $0.201^{* *}$ & -0.01 & $0.201^{* *}$ & -0.01 \\
\hline
\end{tabular}




\begin{tabular}{|c|c|c|c|c|c|c|c|c|}
\hline & $(0.087)$ & $(0.058)$ & $(0.087)$ & $(0.058)$ & $(0.087)$ & $(0.058)$ & $(0.087)$ & $(0.058)$ \\
\hline \multirow[t]{2}{*}{ Buddhist } & 0.052 & -0.006 & 0.052 & -0.006 & 0.059 & -0.003 & 0.059 & -0.003 \\
\hline & $(0.077)$ & $(0.048)$ & $(0.077)$ & $(0.048)$ & $(0.077)$ & $(0.048)$ & $(0.077)$ & $(0.048)$ \\
\hline \multirow[t]{2}{*}{ Indigenous } & 0.206 & 0.154 & 0.206 & 0.154 & 0.2 & 0.149 & 0.2 & 0.149 \\
\hline & $(0.181)$ & $(0.139)$ & $(0.181)$ & $(0.139)$ & $(0.181)$ & $(0.139)$ & $(0.181)$ & $(0.139)$ \\
\hline \multirow[t]{2}{*}{ Jew } & $0.359^{*}$ & $0.312^{* *}$ & $0.359^{*}$ & $0.312^{* *}$ & $0.385^{*}$ & $0.319^{* *}$ & $0.385^{*}$ & $0.319^{* *}$ \\
\hline & $(0.199)$ & $(0.135)$ & $(0.199)$ & $(0.135)$ & $(0.199)$ & $(0.135)$ & $(0.199)$ & $(0.135)$ \\
\hline \multirow[t]{2}{*}{ Social1 } & $-0.345^{* * *}$ & $-0.106^{* * *}$ & & & $-0.502^{* * *}$ & $-0.125^{* * *}$ & & \\
\hline & $(0.036)$ & $(0.025)$ & & & $(0.048)$ & $(0.034)$ & & \\
\hline \multirow[t]{2}{*}{ Social2 } & 0.017 & 0.012 & $0.362^{* * *}$ & $0.119^{* * *}$ & -0.043 & 0.046 & $0.46^{* * *}$ & $0.171^{* * *}$ \\
\hline & $(0.037)$ & $(0.026)$ & $(0.02)$ & $(0.014)$ & $(0.05)$ & $(0.035)$ & $(0.028)$ & $(0.02)$ \\
\hline \multirow[t]{2}{*}{ Social3 } & $0.108^{* * *}$ & 0.021 & $0.453^{* * *}$ & $0.127^{* * *}$ & $0.124^{* *}$ & 0.058 & $0.626^{* * *}$ & $0.183^{* * *}$ \\
\hline & $(0.04)$ & $(0.028)$ & $(0.027)$ & $(0.019)$ & $(0.056)$ & $(0.039)$ & $(0.037)$ & $(0.026)$ \\
\hline \multirow[t]{2}{*}{ Social4 } & & & $0.345^{* * *}$ & $0.106^{* * *}$ & & & $0.502^{* * *}$ & $0.125^{* * *}$ \\
\hline & & & $(0.036)$ & $(0.025)$ & & & $(0.048)$ & $(0.034)$ \\
\hline Social1 * & & & & & $0.334^{* * *}$ & 0.036 & & \\
\hline Relig. Serv. & & & & & $(0.069)$ & $(0.049)$ & & \\
\hline Social2 * & & & & & $0.138^{*}$ & -0.067 & $-0.196^{* * *}$ & $-0.103^{* * *}$ \\
\hline Relig. Serv. & & & & & $(0.073)$ & $(0.051)$ & $(0.039)$ & $(0.027)$ \\
\hline Social3 * & & & & & -0.022 & -0.077 & $-0.357^{* * *}$ & $-0.113^{* * *}$ \\
\hline Relig. Serv. & & & & & $(0.08)$ & $(0.056)$ & $(0.052)$ & $(0.036)$ \\
\hline Social4 * & & & & & & & $-0.334^{* * *}$ & -0.036 \\
\hline Relig. Serv. & & & & & & & $(0.069)$ & $(0.049)$ \\
\hline \multirow[t]{2}{*}{ Constant } & $1.361^{* * *}$ & & $1.016^{* * *}$ & & $1.452^{* * *}$ & & $0.95^{* * *}$ & \\
\hline & $(0.163)$ & & $(0.16)$ & & $(0.166)$ & & $(0.161)$ & \\
\hline $\begin{array}{l}\text { Number of } \\
\text { Observations }\end{array}$ & 82,025 & 94,777 & 82,025 & 94,777 & 82,025 & 94,777 & 82,025 & 94,777 \\
\hline $\begin{array}{l}\text { Pseudo R- } \\
\text { squared }\end{array}$ & 0.0985 & 0.0887 & 0.0985 & 0.0887 & 0.0992 & 0.0887 & 0.0992 & 0.0887 \\
\hline $\begin{array}{l}\text { Country } \\
\text { Dummies }\end{array}$ & yes & yes & yes & yes & yes & yes & yes & yes \\
\hline
\end{tabular}

Source: Gallup World Poll (2005-2011).

Notes: All regressions use robust standard errors and country dummies. We treat the sample as a pooled cross section and therefore do not include year dummies. BPL measures the respondent's assessment of her current life relative to her best possible life. Happy is a binary variable coded 1 if the respondent experienced happiness the day before and 0 otherwise. Household income is log-transformed and is in international dollars (ID), which allows comparisons across countries and time. Models $(1,3,5,7)$ are estimated using logit while Models $(2,4,6,8)$ are estimated using ordered logit. Social1 refers to the least social individuals.

${ }^{* * *} \mathrm{p}<0.01,{ }^{* *} \mathrm{p}<0.05,{ }^{*} \mathrm{p}<0.10$

Rather surprisingly, our interaction term (sociability * religious services attendance) is negative and significant for all of the social groups compared to the least social one. The combined effect of the interaction term and the social variables in each instance mitigates the positive effects of socializing but does not eliminate them. When we alter the specification and leave out the most social group and include the least happy, least social group in our regressions, we get a positive coefficient on that group; in this instance the interaction term mitigates the negative effect of being in that least social group on daily experience. The findings suggest that for the least social group religious services provide a positive form of socialization, which the already more social cohorts either do not need or do not notice.

Interestingly, in the specification in which we include our social variables, the one religion that has a significant difference in results is Judaism. With the inclusion of the social variables, the positive correlation between Judaism and happy yesterday disappears, and drops significantly for bpl. To the extent that our results on Judaism are driven by the shared identity 
and purpose that Jews in Israel have (and 90\% of Jewish respondents in the GWP are in Israel), and that the social aspects of religion are recognized to be part of Jewish identity there, then the social factors are likely the positive drivers behind the initial correlations in Table 2 (above). In contrast, Jewish respondents in the U.S. General Social Survey are significantly less happy than the average U.S. respondent. ${ }^{27}$ As in the case of the study (cited above) by Mookerjee and Beron (1995), the extent of religious fractionalization in the U.S. compared to the prevalence of Judaism in Israel may play a role.

Jeff Levin, for example, in results based on a 900 plus sample of Jewish adults in 2009-2010, finds that a wide number of religious measures (ranging from attending synagogue to certainty of belief in God to subjective religiosity) were significantly associated with happiness. In contrast, they find that prayer is negatively associated with mental health indicators, perhaps because prayer is more likely to be a coping strategy at times of adversity than is attending services. ${ }^{28} \mathrm{He}$ cites a growing body of population-based studies supporting a salutatory impact of Jewish religious observance on subjective wellbeing in Israel and the diaspora. Presumably this plays out differently in the United States.

\subsection{Differences between Christian dominated and non-Christian dominated countries}

When we split our sample into countries with a Christian majority and those without a Christian majority, our priors were that people of different religious affiliation might have different experiences depending on whether the religion with which they were affiliated was in the majority or not. An additional factor is that the mean income in the sample with a majority of Christians is twice as high as that for the sample with a non-Christian majority. In each case, our left-out category was the non-religious group and we include country dummies. The results for our two religions variables are roughly the same in this split sample specification as they were for the full sample. There are, however, some significant changes across religious affiliations (see Table 4 below).

In the non-Christian majority sample, the coefficient on Muslim, Shiites, and Sunnis, which had mixed results in the other specifications, become positive and significant for happy yesterday, as does that for Hindus. There is not a consistent relationship with bpl for the same religions. Jews retain positive scores on both dimensions. The coefficients on Protestant and Catholic, meanwhile, become insignificant when these religions are in the minority. These results are suggestive, again, of the role of religious homogeneity versus fractionalization in the relationship with wellbeing.

Table 4. Regression analysis of evaluative and hedonic wellbeing, Christian majority/nonmajority split sample

\begin{tabular}{lcccc}
\hline & \multicolumn{2}{c}{ Christian Majority } & \multicolumn{2}{c}{ Non-Christian Majority } \\
\cline { 2 - 5 } & Happy & BPL & Happy & BPL \\
& $\mathbf{( 1 )}$ & $\mathbf{( 2 )}$ & $\mathbf{( 3 )}$ & $\mathbf{( 4 )}$ \\
\hline Religion Important & $0.182^{* * *}$ & 0.007 & $0.113^{* * *}$ & 0.013 \\
& $(0.018)$ & $(0.013)$ & $(0.021)$ & $(0.016)$ \\
Religious Service & $0.149^{* * *}$ & $0.11^{* * *}$ & $0.197^{* * *}$ & $0.095^{* * *}$
\end{tabular}

\footnotetext{
${ }^{27}$ Results based on our analysis of the U.S. General Social Survey data. Available from the authors upon request.

${ }^{28}$ Jeff Levin (2013), "Religion and Mental Health among Israeli Jews: Findings from the SHARE-Israel Study", Social Indicators Research, Vol. 113, 769-784.
} 


$\begin{array}{lcccc} & (0.016) & (0.011) & (0.015) & (0.011) \\ \text { Urban } & 0.017 & 0.133^{* * *} & 0.053^{* * *} & 0.167^{* * *} \\ \text { Household Size } & (0.014) & (0.01) & (0.015) & (0.011) \\ & 0.011^{* *} & 0.003 & -0.003 & -0.006^{* *} \\ \text { Ln(Household income) } & (0.005) & (0.003) & (0.003) & (0.003) \\ & 0.138^{* * *} & 0.295^{* * *} & 0.213^{* * *} & 0.438^{* * *} \\ \text { Gender } & (0.006) & (0.005) & (0.007) & (0.006) \\ & -0.045^{* * *} & 0.033^{* * *} & 0.066^{* * *} & 0.089^{* * *} \\ \text { Age (in years) } & (0.013) & (0.009) & (0.013) & (0.01) \\ & -0.047^{* * *} & -0.046^{* * *} & -0.042^{* * *} & -0.023^{* * *} \\ \text { Age-Squared } & (0.002) & (0.001) & (0.002) & (0.002) \\ & 0.00032^{* * *} & 0.00036^{* * *} & 0.00032^{* * *} & 0.00018^{* * *} \\ \text { Marital Status } & (0.00002) & (0.00002) & (0.00003) & (0.00002) \\ & 0.292^{* * *} & 0.13^{* * *} & 0.225^{* * *} & 0.1^{* * *} \\ \text { Education } & (0.014) & (0.01) & (0.016) & (0.012) \\ & 0.165^{* * *} & 0.414^{* * *} & 0.211^{* * *} & 0.4^{* * *} \\ & (0.02) & (0.013) & (0.022) & (0.016)\end{array}$

Religion Categories (Ref. Group: Non-religious)

$\begin{array}{lcccc}\text { Other Religion } & 0.127^{* * *} & 0.102^{* * *} & 0.13^{*} & 0.187^{* * *} \\ \text { Christian } & (0.044) & (0.032) & (0.074) & (0.055) \\ & 0.149^{*} & -0.053 & 0.122 & -0.011 \\ \text { Catholic Christian } & (0.078) & (0.049) & (0.084) & (0.058) \\ & 0.157^{* * *} & 0.032 & 0.124^{* *} & -0.065 \\ \text { Protestant Christian } & (0.032) & (0.023) & (0.063) & (0.045) \\ & 0.216^{* * *} & 0.054^{* *} & 0.091 & -0.002 \\ \text { Orthodox Christian } & (0.034) & (0.024) & (0.07) & (0.05) \\ & 0.138^{* * *} & -0.08^{* * *} & 0.124^{*} & -0.228^{* * *} \\ \text { Muslim } & (0.041) & (0.03) & (0.072) & (0.053) \\ \text { Shiite Muslim } & 0.1^{* *} & -0.079^{* *} & 0.227^{* * *} & 0.056 \\ & (0.045) & (0.032) & (0.059) & (0.041) \\ \text { Sunni Muslim } & 0.112 & 0.025 & 0.228^{* * *} & -0.097^{*} \\ & (0.12) & (0.09) & (0.068) & (0.051) \\ \text { Druze } & -0.062 & -0.099^{*} & 0.191^{* * *} & -0.022 \\ & (0.077) & (0.056) & (0.061) & (0.044) \\ & 0.216 & 0.229 & 0.233 & 0.237^{*} \\ & (0.557) & (0.382) & (0.146) & (0.124)\end{array}$

Table 4 (cont.). Regression analysis of evaluative and hedonic wellbeing, Christian majority/non-majority split sample

\begin{tabular}{lllcc}
\hline & \multicolumn{2}{c}{ Christian Majority } & \multicolumn{2}{c}{ Non-Christian Majority } \\
\cline { 2 - 5 } & Happy & BPL & Happy & BPL \\
& $\mathbf{( 1 )}$ & $\mathbf{( 2 )}$ & $\mathbf{( 3 )}$ & $\mathbf{( 4 )}$ \\
\hline Hindu & -0.337 & $-0.558^{* * *}$ & $0.245^{* * *}$ & $0.117^{* *}$ \\
& $(0.225)$ & $(0.119)$ & $(0.068)$ & $(0.048)$ \\
Buddhist & -0.038 & $-0.298^{* *}$ & $0.093^{*}$ & -0.022
\end{tabular}




\begin{tabular}{lcccc} 
& $(0.202)$ & $(0.139)$ & $(0.052)$ & $(0.036)$ \\
Indigenous & -0.04 & -0.017 & 0.279 & -0.189 \\
& $(0.114)$ & $(0.089)$ & $(0.195)$ & $(0.154)$ \\
Jew & 0.074 & 0.049 & $0.469^{* * *}$ & $0.431^{* * *}$ \\
& $(0.233)$ & $(0.13)$ & $(0.115)$ & $(0.086)$ \\
Constant & $1.683^{* * *}$ & & $-0.728^{* * *}$ & \\
Number of Observations & $(0.118)$ & & $(0.1)$ & \\
Pseudo R-squared & 136,275 & 153,228 & 125,049 & 141,392 \\
Country Dummies & 0.1075 & 0.0815 & 0.0607 & 0.0588 \\
\hline Source Cap & yes & yes & yes & yes \\
\hline
\end{tabular}

Source: Gallup World Poll (2005-2011)

Notes: All regressions use robust standard errors and country dummies. We treat the sample as a pooled cross section and therefore do not include year dummies. BPL measures the respondent's assessment of her current life relative to her best possible life. Happy is a binary variable coded 1 if the respondent experienced happiness the day before and 0 otherwise. Household income is log-transformed and is in international dollars (ID), which allows comparisons across countries and time. Models (1 \& 3) are estimated using logit while Models ( $2 \& 4$ ) are estimated using ordered logit.

${ }^{* * *} \mathrm{p}<0.01,{ }^{* *} \mathrm{p}<0.05,{ }^{*} \mathrm{p}<0.10$

For the majority Christian sample, the coefficients for Catholic and Protestant become positive and significant for happy yesterday but are insignificant on bpl for Catholics. Hedonic wellbeing is thus higher for Catholic and Protestant respondents in Christian majority countries than for Catholics and Protestants in non-Christian majority countries. The coefficient for Muslim remains positive for happy but turns strongly negative for bpl. Judaism once again becomes insignificant on both coefficients (again likely driven by the concentration of Jewish respondents in Israel).

\subsection{Differences among countries of varying income and levels of development}

We next tested whether the relationship between religion and wellbeing (in its two dimensions) varied across countries of different levels of development, with our priors being that respondents in wealthier countries have, on average, greater means and capabilities, and thus different aspects of religion might matter more or less to their wellbeing (and across its dimensions). We split our sample into three income categories (low, middle, and high), based on the World Bank's World Development Indicators (WDI), combining the lower-middle income and upper-middle income categories into one. Again, this splitting of the sample, while producing interesting results, calls for caution in making exact comparisons of coefficient sizes across the sample. We again focus on the direction and significance of the signs rather than the exact coefficient values when we discuss the results in a comparative context.

In previous research (Graham and Chattopadhyay, 2013), it was found that the relationship between marriage and wellbeing varies across countries of different levels of development, with the positive relationship holding only in the wealthiest WDI category. ${ }^{29}$ We find similar patterns with our split samples here, with the coefficients on marriage and gender being insignificant in the sample of poorer countries.

\footnotetext{
${ }^{29}$ In that instance, our interpretation was that marriage was more likely to be positively associated with wellbeing in instances where it was more of a voluntary choice than a result of strong social norms. See Carol Graham and Soumya Chattopadhyay, "Gender and Well-Being around the World", International Journal of Happiness and Development, Vol.1, No.2, 212-232.
} 
Our underlying intuition here was that religion was more likely to be important to wellbeing in poorer countries, where people have lower levels of agency and fewer capabilities, and therefore less control over the course of their lives. Our results support our hypothesis.

We find that for the first income category (the poorest countries) the coefficients on both religion important and religious services are positively and significantly correlated with happy. The coefficient on religious services is positively correlated with the best possible life, but believing that religion is important is insignificant. We get a similar pattern and roughly similar coefficients and $t$-values for the middle-income countries. For the richest countries, however, while the same pattern holds for hedonic wellbeing, the positive coefficient values are much weaker. For bpl, the coefficient on religious services remains positive but religion is important turns negative (and insignificant) (see Table 5). All these results provide modest support for religion mattering more in poor countries, and religion's relationship with the evaluative dimension of wellbeing (and therefore implicitly agency and capability) is weakest in the richest countries, where people have greater means and more control over the course of their lives.

Table 5. Regression analysis of evaluative and hedonic wellbeing, split sample by income

\begin{tabular}{|c|c|c|c|c|c|c|}
\hline & \multicolumn{2}{|c|}{ WDI 1} & \multicolumn{2}{|c|}{ WDI 2} & \multicolumn{2}{|c|}{ WDI 3} \\
\hline & $\begin{array}{c}\text { Happy } \\
\text { (1) }\end{array}$ & $\begin{array}{c}\text { BPL } \\
(2) \\
\end{array}$ & $\begin{array}{c}\text { Happy } \\
\text { (3) }\end{array}$ & $\begin{array}{c}\text { BPL } \\
(4) \\
\end{array}$ & $\begin{array}{c}\text { Happy } \\
\text { (5) }\end{array}$ & $\begin{array}{l}\text { BPL } \\
(6)\end{array}$ \\
\hline Religion Important & $\begin{array}{l}0.225^{* * *} \\
(0.041)\end{array}$ & $\begin{array}{c}0.051 \\
(0.033)\end{array}$ & $\begin{array}{l}0.154^{* * *} \\
(0.018)\end{array}$ & $\begin{array}{c}0.014 \\
(0.013)\end{array}$ & $\begin{array}{l}0.123^{* * *} \\
(0.026)\end{array}$ & $\begin{array}{l}-0.021 \\
(0.018)\end{array}$ \\
\hline Religious Service & $\begin{array}{l}0.228^{* * *} \\
(0.022)\end{array}$ & $\begin{array}{c}0.13^{* * *} \\
(0.017)\end{array}$ & $\begin{array}{l}0.149^{* * *} \\
(0.014)\end{array}$ & $\begin{array}{l}0.072^{* * *} \\
(0.01)\end{array}$ & $\begin{array}{l}0.144^{* * *} \\
(0.026)\end{array}$ & $\begin{array}{l}0.168^{* * *} \\
(0.018)\end{array}$ \\
\hline Urban & $\begin{array}{l}0.057^{* *} \\
(0.025)\end{array}$ & $\begin{array}{l}0.236^{* * *} \\
(0.019)\end{array}$ & $\begin{array}{l}0.04^{* * *} \\
(0.013)\end{array}$ & $\begin{array}{l}0.173^{* * *} \\
(0.009)\end{array}$ & $\begin{array}{l}-0.02 \\
(0.023)\end{array}$ & $\begin{array}{c}0.019 \\
(0.015)\end{array}$ \\
\hline Household Size & $\begin{array}{l}-0.001 \\
(0.005)\end{array}$ & $\begin{array}{l}0.01^{* * *} \\
(0.004)\end{array}$ & $\begin{array}{c}0.005 \\
(0.004)\end{array}$ & $\begin{array}{l}-0.008^{* * *} \\
(0.003)\end{array}$ & $\begin{array}{l}-0.005 \\
(0.008)\end{array}$ & $\begin{array}{l}-0.009 \\
(0.006)\end{array}$ \\
\hline Ln(Househ. income) & $\begin{array}{l}0.164^{* * *} \\
(0.009)\end{array}$ & $\begin{array}{l}0.358^{* * *} \\
(0.007)\end{array}$ & $\begin{array}{l}0.183^{* * *} \\
(0.006)\end{array}$ & $\begin{array}{l}0.356^{* * *} \\
(0.005)\end{array}$ & $\begin{array}{l}0.129^{* * *} \\
(0.01)\end{array}$ & $\begin{array}{l}0.334^{* * *} \\
(0.009)\end{array}$ \\
\hline Gender & $\begin{array}{l}-0.011 \\
(0.019)\end{array}$ & $\begin{array}{l}-0.02 \\
(0.014)\end{array}$ & $\begin{array}{c}0.008 \\
(0.012)\end{array}$ & $\begin{array}{l}0.061^{* * *} \\
(0.009)\end{array}$ & $\begin{array}{c}0.05^{* *} \\
(0.021)\end{array}$ & $\begin{array}{l}0.143^{* * *} \\
(0.014)\end{array}$ \\
\hline Age (in years) & $\begin{array}{l}-0.021^{* * *} \\
(0.003)\end{array}$ & $\begin{array}{l}-0.005^{*} \\
(0.002)\end{array}$ & $\begin{array}{l}-0.044^{* * *} \\
(0.002)\end{array}$ & $\begin{array}{l}-0.037^{* * *} \\
(0.001)\end{array}$ & $\begin{array}{l}-0.066^{* * *} \\
(0.004)\end{array}$ & $\begin{array}{l}-0.06^{* * *} \\
(0.002)\end{array}$ \\
\hline Age-Squared & $\begin{array}{l}0.00009^{* * *} \\
(0.00004)\end{array}$ & $\begin{array}{l}-0.00001 \\
(0.00003)\end{array}$ & $\begin{array}{l}0.0003^{* * *} \\
(0.00002)\end{array}$ & $\begin{array}{l}0.00027^{* * *} \\
(0.00002)\end{array}$ & $\begin{array}{l}0.00053^{* * *} \\
(0.00004)\end{array}$ & $\begin{array}{l}0.00051^{* * *} \\
(0.00002)\end{array}$ \\
\hline Marital Status & $\begin{array}{l}0.095^{* * *} \\
(0.022)\end{array}$ & $\begin{array}{c}0.003 \\
(0.017)\end{array}$ & $\begin{array}{l}0.267^{* * *} \\
(0.014)\end{array}$ & $\begin{array}{l}0.094^{* * *} \\
(0.01)\end{array}$ & $\begin{array}{l}0.473^{* * *} \\
(0.023)\end{array}$ & $\begin{array}{l}0.343^{* * *} \\
(0.017)\end{array}$ \\
\hline
\end{tabular}

Table 5 (cont.). Regression analysis of evaluative and hedonic wellbeing, split sample by income

\begin{tabular}{lcccccc}
\hline & \multicolumn{2}{c}{ WDI 1 } & \multicolumn{2}{c}{ WDI 2 } & \multicolumn{2}{c}{ WDI 3 } \\
\cline { 2 - 7 } & Happy & BPL & Happy & BPL & Happy & BPL \\
& $\mathbf{( 1 )}$ & $\mathbf{( 2 )}$ & $\mathbf{( 3 )}$ & $\mathbf{( 4 )}$ & $\mathbf{( 5 )}$ & $\mathbf{( 6 )}$ \\
\hline Education & $0.293^{* * *}$ & $0.404^{* * *}$ & $0.219^{* * *}$ & $0.434^{* * *}$ & $0.095^{* * *}$ & $0.362^{* * *}$ \\
& $(0.05)$ & $(0.036)$ & $(0.019)$ & $(0.014)$ & $(0.026)$ & $(0.017)$ \\
Other Religion & -0.019 & 0.076 & $0.224^{* *}$ & 0.074 & 0.121 & $-0.161^{* * *}$ \\
& $(0.201)$ & $(0.163)$ & $(0.087)$ & $(0.06)$ & $(0.086)$ & $(0.054)$ \\
Christian & 0.089 & $0.269^{* *}$ & $0.121^{* *}$ & $0.195^{* * *}$ & $0.185^{* * *}$ & 0.054
\end{tabular}




\begin{tabular}{lcccccc} 
& $(0.161)$ & $(0.132)$ & $(0.06)$ & $(0.045)$ & $(0.061)$ & $(0.042)$ \\
Catholic Christian & $0.251^{*}$ & $0.248^{* *}$ & $0.115^{* *}$ & -0.001 & $0.15^{* * *}$ & -0.019 \\
& $(0.15)$ & $(0.123)$ & $(0.049)$ & $(0.036)$ & $(0.039)$ & 0 \\
Protestant Christian & $0.322^{* *}$ & $0.239^{*}$ & $0.122^{* *}$ & -0.009 & $0.247^{* * *}$ & $0.083^{* * *}$ \\
& $(0.15)$ & $(0.123)$ & $(0.053)$ & $(0.038)$ & $(0.043)$ & $(0.029)$ \\
Orthodox Christian & 0.147 & -0.058 & $0.149^{* * *}$ & -0.04 & 0.09 & $-0.113^{* *}$ \\
& $(0.166)$ & $(0.137)$ & $(0.052)$ & $(0.038)$ & $(0.078)$ & $(0.057)$ \\
Muslim & 0.242 & 0.121 & $0.178^{* * *}$ & $0.128^{* * *}$ & 0.05 & $-0.5^{* * *}$ \\
Shiite Muslim & $(0.15)$ & $(0.124)$ & $(0.052)$ & $(0.038)$ & $(0.089)$ & $(0.063)$ \\
& $0.532^{* * *}$ & 0.075 & 0.083 & -0.021 & -0.447 & $-0.783^{* *}$ \\
Sunni Muslim & $(0.166)$ & $(0.135)$ & $(0.064)$ & $(0.049)$ & $(0.426)$ & $(0.315)$ \\
& $0.323^{* *}$ & 0.135 & 0.086 & 0.037 & $-0.463^{* *}$ & $-0.508^{* * *}$ \\
Druze & $(0.155)$ & $(0.127)$ & $(0.056)$ & $(0.041)$ & $(0.189)$ & $(0.143)$ \\
& -0.642 & 0.016 & 0.189 & $0.301^{* *}$ & 0.389 & 0.066 \\
Hindu & $(0.502)$ & $(0.399)$ & $(0.152)$ & $(0.127)$ & $(0.451)$ & $(0.334)$ \\
Buddhist & 0.085 & 0.081 & $0.279^{* * *}$ & $0.213^{* * *}$ & 0.129 & $-0.455^{* * *}$ \\
& $(0.182)$ & $(0.144)$ & $(0.071)$ & $(0.049)$ & $(0.141)$ & $(0.095)$ \\
Indigenous & $0.468^{* *}$ & 0.111 & $-0.139^{* *}$ & $0.135^{* * *}$ & $0.166^{* * *}$ & $-0.168^{* * *}$ \\
Jew & $(0.218)$ & $(0.157)$ & $(0.07)$ & $(0.048)$ & $(0.058)$ & $(0.039)$ \\
Constant & $0.367^{*}$ & 0.188 & $-0.258^{*}$ & $-0.202^{*}$ & 0.76 & -0.02 \\
& $(0.194)$ & $(0.159)$ & $(0.154)$ & $(0.123)$ & $(0.622)$ & $(0.328)$ \\
Number of Observations & & 0.427 & -0.031 & -0.127 & $0.367^{* * *}$ & $0.183^{* *}$ \\
Pseudo R-squared & 0.17996 & 62,982 & 146,284 & 167,040 & 57,043 & 64,598 \\
Country Dummies & yes & 0.0358 & 0.0912 & 0.0438 & 0.0923 & 0.0639 \\
\hline
\end{tabular}

Source: Gallup World Poll (2005-2011)

Notes: All regressions use robust standard errors and country dummies. We treat the sample as a pooled cross section and therefore do not include year dummies. BPL measures the respondent's assessment of her current life relative to her best possible life. Happy is a binary variable coded 1 if the respondent experienced happiness the day before and 0 otherwise. Household income is log-transformed and is in international dollars (ID), which allows comparisons across countries and time. Models $(1,3,5)$ are estimated using logit while Models $(2,4,6)$ are estimated using ordered logit. WDI 1 refers to the poorest countries.

${ }^{* * *} \mathrm{p}<0.01,{ }^{* *} \mathrm{p}<0.05,{ }^{*} \mathrm{p}<0.10$

While we do not get a systematic pattern across religious affiliations, there is one notable trend. The coefficients on non-Christian religions, which are more positive in the poorer countries, get markedly more negative in the sample of the wealthiest countries, particularly on the bpl variable. Presumably being affiliated with a minority religion can be a factor working against getting ahead in society, and particularly in contexts of great wealth, where those religions are even more in the minority (and/or there is more fractionalization), and where getting to the top is that much harder. In contrast, the insignificant coefficient on bpl for Protestants becomes positive and significant in the sample of richest countries.

\subsection{Results from quantile regressions}

Finally, we relied on quantile regressions to explore how or if the relationship between religion and wellbeing varied depending where respondents were in the wellbeing distribution. While this exercise cannot fully answer the direction of causality question - whether happier people are 
more likely to be religious or whether religion makes people happier - at least it can tell us if the relationship between religion and wellbeing is more important for the happiest part of our sample than for others (and if there is variance across the wellbeing dimensions depending on where respondents are in the wellbeing distribution).

Our results support our priors. Attending religious services is significantly and positively associated with bpl across all of the quantiles. Religion is important, although it is insignificant for the two least happy quantiles (q25 and q50) and positive and significant for the two happiest quantiles (q75 and q90). It seems that the positive association between religiosity (rather than religious practice) is driven by the happier half of the distribution. At the same time the importance of religion increases, as people get happier, the magnitude of the coefficient on income decreases as we move up the happiness quantiles (see Table 6).

Table 6: Regression analysis of evaluative and hedonic wellbeing, best possible life quantile regressions-religion categories (ref. group: non-religious)

\begin{tabular}{lcccc}
\hline & $\begin{array}{c}\text { Q25 } \\
\text { quantile }\end{array}$ & $\begin{array}{c}\text { Q50 } \\
\text { quantile }\end{array}$ & $\begin{array}{c}\text { Q75 } \\
\text { quantile }\end{array}$ & $\begin{array}{c}\text { Q90 } \\
\text { quantile }\end{array}$ \\
\hline Religion Important & $\mathbf{( 1 )}$ & $\mathbf{( 2 )}$ & $\mathbf{( 3 )}$ & $\mathbf{( 4 )}$ \\
\hline Religious Service & -0.012 & 0.002 & $0.048^{* * *}$ & $0.102^{* * *}$ \\
& $(0.013)$ & $(0.011)$ & $(0.014)$ & $(0.017)$ \\
Urban & $0.098^{* * *}$ & $0.083^{* * *}$ & $0.101^{* * *}$ & $0.098^{* * *}$ \\
& $(0.008)$ & $(0.008)$ & $(0.008)$ & $(0.009)$ \\
Household Size & $0.101^{* * *}$ & $0.12^{* * *}$ & $0.183^{* * *}$ & $0.188^{* * *}$ \\
Ln(Household income) & $(0.01)$ & $(0.007)$ & $(0.012)$ & $(0.016)$ \\
Gender & $-0.01^{* * * *}$ & -0.004 & 0.002 & 0.005 \\
Age (in years) & $(0.003)$ & $(0.003)$ & $(0.003)$ & $(0.004)$ \\
& $0.503^{* * *}$ & $0.365^{* * *}$ & $0.277^{* * *}$ & $0.202^{* * *}$ \\
Age-Squared & $(0.008)$ & $(0.005)$ & $(0.005)$ & $(0.006)$ \\
& $0.057^{* * *}$ & $0.053^{* * *}$ & $0.061^{* * *}$ & $0.09^{* * *}$ \\
Marital Status & $(0.009)$ & $(0.008)$ & $(0.009)$ & $(0.008)$ \\
& $-0.03^{* * *}$ & $-0.029^{* * *}$ & $-0.036^{* * *}$ & $-0.046^{* * *}$ \\
& $(0.001)$ & $(0.001)$ & $(0.002)$ & $(0.002)$ \\
& $0.00019^{* * *}$ & $0.00021^{* * *}$ & $0.00031^{* * *}$ & $0.00045^{* * *}$ \\
& $(0.00001)$ & $(0.00001)$ & $(0.00002)$ & $(0.00003)$ \\
& $0.142^{* * *}$ & $0.111^{* * *}$ & $0.096^{* * *}$ & $0.112^{* * *}$
\end{tabular}

Table 6: Regression analysis of evaluative and hedonic wellbeing, best possible life quantile regressions-religion categories (ref. group: non-religious)

\begin{tabular}{lcccc}
\hline & $\begin{array}{c}\text { Q25 } \\
\text { quantile } \\
\text { (1) }\end{array}$ & $\begin{array}{c}\text { Q50 } \\
\text { quantile } \\
\text { (2) }\end{array}$ & $\begin{array}{c}\text { Q75 } \\
\text { quantile } \\
\text { Education }\end{array}$ & $\begin{array}{c}\text { Q90 } \\
\text { quantile }\end{array}$ \\
\hline \multirow{3}{*}{ Other Religion } & $0.426^{* * *}$ & $0.373^{* * *}$ & $0.37^{* * *}$ & $0.234^{* * *}$ \\
& $(0.013)$ & $(0.015)$ & $(0.016)$ & $(0.02)$ \\
Christian & $-0.103^{*}$ & -0.027 & -0.012 & 0.02 \\
& $(0.057)$ & $(0.032)$ & $(0.044)$ & $(0.064)$ \\
& $0.102^{* * *}$ & $0.094^{* * *}$ & $0.099^{* *}$ & $0.123^{* * *}$
\end{tabular}




\begin{tabular}{|c|c|c|c|c|}
\hline & $(0.036)$ & $(0.031)$ & $(0.041)$ & $(0.038)$ \\
\hline \multirow[t]{2}{*}{ Catholic Christian } & 0.026 & 0.026 & -0.021 & 0.016 \\
\hline & $(0.021)$ & $(0.024)$ & $(0.021)$ & $(0.022)$ \\
\hline \multirow[t]{2}{*}{ Protestant Christian } & 0.024 & $0.053^{* *}$ & 0.044 & $0.089^{* * *}$ \\
\hline & $(0.019)$ & $(0.024)$ & $(0.027)$ & $(0.026)$ \\
\hline \multirow[t]{2}{*}{ Orthodox Christian } & $-0.121^{* * *}$ & $-0.089^{* * *}$ & $-0.166^{* * *}$ & $-0.111^{* * *}$ \\
\hline & $(0.027)$ & $(0.027)$ & $(0.031)$ & $(0.034)$ \\
\hline \multirow[t]{2}{*}{ Muslim } & 0.016 & -0.002 & -0.018 & $0.066^{*}$ \\
\hline & $(0.029)$ & $(0.024)$ & $(0.03)$ & $(0.035)$ \\
\hline \multirow[t]{2}{*}{ Shiite Muslim } & $-0.173^{* * *}$ & $-0.084^{* *}$ & -0.09 & -0.068 \\
\hline & $(0.048)$ & $(0.036)$ & $(0.061)$ & $(0.045)$ \\
\hline \multirow[t]{2}{*}{ Sunni Muslim } & $-0.07^{*}$ & $-0.074^{* * *}$ & $-0.076^{* *}$ & -0.022 \\
\hline & $(0.036)$ & $(0.02)$ & $(0.03)$ & $(0.034)$ \\
\hline \multirow[t]{2}{*}{ Druze } & $0.239^{*}$ & 0.102 & 0.001 & -0.112 \\
\hline & $(0.139)$ & $(0.142)$ & $(0.147)$ & $(0.191)$ \\
\hline \multirow[t]{2}{*}{ Hindu } & $0.094^{*}$ & 0.029 & -0.028 & 0.006 \\
\hline & $(0.053)$ & $(0.026)$ & $(0.043)$ & $(0.076)$ \\
\hline \multirow[t]{2}{*}{ Buddhist } & -0.014 & $-0.058^{*}$ & -0.032 & 0.062 \\
\hline & $(0.028)$ & $(0.029)$ & $(0.045)$ & $(0.049)$ \\
\hline \multirow[t]{2}{*}{ Indigenous } & -0.008 & -0.043 & 0.004 & -0.212 \\
\hline & $(0.124)$ & $(0.094)$ & $(0.067)$ & $(0.162)$ \\
\hline \multirow[t]{2}{*}{ Jew } & $0.583^{* * *}$ & $0.286^{* * *}$ & $0.196^{* *}$ & $0.186^{* *}$ \\
\hline & $(0.097)$ & $(0.078)$ & $(0.099)$ & $(0.085)$ \\
\hline \multirow[t]{2}{*}{ Constant } & $1.502^{* * *}$ & $4.125^{* * *}$ & $6.107^{* * *}$ & $7.994^{* * *}$ \\
\hline & $(0.091)$ & $(0.072)$ & $(0.082)$ & $(0.127)$ \\
\hline Number of Observations & 294,620 & 294,620 & 294,620 & 294,620 \\
\hline Pseudo R-squared & 0.1462 & 0.1496 & 0.1746 & 0.1316 \\
\hline Country Dummies & yes & yes & yes & yes \\
\hline
\end{tabular}

Source: Gallup World Poll (2005-2011)

Notes: All regressions use bootstrapped standard errors and country dummies. We treat the sample as a pooled cross section and therefore do not include year dummies. BPL measures the respondent's assessment of her current life relative to her best possible life. Happy is a binary variable coded 1 if the respondent experienced happiness the day before and 0 otherwise. Household income is log-transformed and is in international dollars (ID), which allows comparisons across countries and time. Q1 is the lowest quantile (25th) and Q4 is the highest (90th).

*** $\mathrm{p}<0.01,{ }^{* *} \mathrm{p}<0.05,{ }^{*} \mathrm{p}<0.10$

\section{Conclusions}

A number of previous studies of religion and wellbeing suggest that the relationship is moderated by the particular dimension of wellbeing that is at question (daily experience versus evaluative). To our knowledge, this the first extensive exploration of this question based on a world-wide sample, with a particular focus on the different dimensions of wellbeing and how their importance might vary across countries of different levels of development. Our underlying hypothesis was that religion was more likely to be important to the daily experience dimension of wellbeing in general, and that its importance to evaluative wellbeing would be higher among poorer respondents with less control over the course of their lives.

Our baseline results support this hypothesis. Both religious variables (religion is important and attending religious services) are positively and significantly correlated with our experienced 
wellbeing variable. Attending religious services is also positively correlated with the best possible life question (our evaluative measure), but reporting that religion is important is insignificant. This is in keeping with our priors, as those respondents with higher bpl scores, who typically also have more means and capabilities, are less likely to rely on religion to determine the course of their lives or as they assess their lives.

Our analysis across poor and rich countries is also suggestive along these lines. Both religious variables were positively and significantly correlated with experienced wellbeing for poor and middle-income countries, while the results on evaluative wellbeing were positive but not always significant. For the rich country sample, the positive coefficients were smaller in magnitude, and the sign on religion is important was negative (but insignificant) with best possible life. Presumably, as people have more means and agency to determine the course of their lives, religion plays a smaller role when they evaluate their lives as a whole, even though it may still be an important part of their daily experiences. Respondents with fewer means and less agency and who face more adversity through the course of their lives seem more likely to turn to religion as a source of hope and/or social insurance.

We posited that one channel through which religion could enhance wellbeing was the social externalities that it provides, as has been suggested by other studies. We find, as expected, that respondents who socialize more frequently have higher scores in both dimensions of wellbeing. Yet the additional positive effect of attending religious services was additionally important only for the least social respondents, perhaps because religion gives them a necessary impetus to socialize. In contrast, attending religious services had a modest negative mitigating effect on the wellbeing of our highly social respondents.

We explored whether the relationship between religion and wellbeing was different depending on whether respondents belonged to the majority affiliation or not. When we split our sample into Christian and non-Christian majority countries, we found significant differences across religions. Compared to the non-religious, Muslim respondents, for example, scored much higher on happy yesterday in the non-Christian majority sample, but scored much lower than the average on best possible life in the Christian majority sample. Jews, meanwhile, scored significantly higher on both wellbeing variables in the non-Christian majority sample (in which most Jewish respondents live in Israel), but not so in the Christian majority sample (where Jewish respondents are primarily in the United States). Protestants and Catholics, meanwhile, scored higher on happy yesterday in the Christian majority sample. As such, the positive relationship between religion and wellbeing seems to be stronger when one's affiliation is closer to the majority affiliation.

As a means to shed light on the difficult question of whether religious people are happier or happier people are more likely to be religious, we analyzed our sample at different quantiles of the wellbeing distribution. We find that the positive association between attending religious services and best possible life holds across all the quantiles. In contrast, the positive association between bpl and religion is important only holds for the happiest quantiles. With the quantile specification, meanwhile, the coefficients on religious affiliation, for the most part, became negative or insignificant. This suggests that happier people are more likely to be religious in the spiritual and emotional sense, their particular religious affiliation aside. While it does not solve the causality problem, it suggests that happier people are more likely to be religious regardless of the religion that they practice - perhaps in the same way that more social people are happier, regardless of whether or not they attend religious services.

Our previous work on agency and wellbeing suggests that the happiest people are happy regardless of many of the variables that proxy for capabilities, such as employment and health. 
Indeed, the same findings show that the happiest people are not necessarily happy in full-time employment, although they are when learning or being creative. The religiosity findings run in the same direction, in that the happiest people are religious regardless of religious affiliation, suggesting that at least some of the causality runs from happiness to religiosity.

In sum, like many others we find a positive relation between religion and wellbeing. We find that the positive relation between evaluative wellbeing is more important for those respondents with lower levels of agency, while the positive relation with hedonic wellbeing holds across the board. The social dimension of religion, meanwhile, was most important for the least social respondents, while the religiosity component of religion was most important for the happiest respondents, regardless of religious affiliation or service attendance. It seems that the happiest are most likely to seek social purpose in religion, the poorest are most likely to seek social insurance in religion, and the least social are the most likely to seek social time in religion.

\section{Acknowledgments}

The authors thank Soumya Chattopadhyay and Milena Nikolova for helpful comments and insights on the data, and two anonymous reviewers for very helpful suggestions.

\section{Authors}

Carol Graham

The Brookings Institution \& University of Maryland

cgraham@brookings.edu

Sarah Crown

University of Nevada at Las Vegas

\section{Publishing Timeline}

Received 8 October 2014

Accepted 3 February 2014

Published 5 June 2014

\section{References}

Ardelt, M. (2003), Effects of religion and purpose in life on elders' subjective well-being and attitudes toward death. Journal of Religious Gerontology, 14(3), 55-77. http://dx.doi.org/10.1300/J078v14n04_04

Binder, M., \& A. Coad (2011), From Average Joe's happiness to Miserable Jane and Cheerful John: Using quantile regressions to analyze the full subjective well-being distribution. Journal of Economic Behavior E Organization, 79(3), 275-290. http://dx.doi.org/10.1016/j.jebo.2011.02.005

Blanchflower, D. \& A. Oswald (2004), Well-being over time in the USA and Britain. Journal of Public Economics, 88, 1359-87. http://dx.doi.org/10.1016/S0047-2727(02)00168-8

Buchinsky, M. (1998), Recent advances in quantile regression models: A practical guideline for empirical research. The Journal of Human Resources, 33(1), 88-126. http://dx.doi.org/10.2307/146316

Cade, B. S. \& B. R. Noon (2003), A gentle introduction to quantile regression for ecologists. Frontiers in Ecology and the Environment, 1(8), 412-420. http://dx.doi.org/10.1890/15409295(2003)001[0412:AGITQR]2.0.CO;2

Clark, A. \& O. Lelkes (2005), “Deliver us from evil: Religion as social insurance”. Paris School of Economics Working Paper.

Clark, A. \& O. Lelkes (2009), "Let us pray: Religious interactions in life satisfaction”. Paris School of Economics Working Paper.

Crown, S. (2013), "Does religion reduce anger and stress around the world?", Master's Thesis, University of Nevada at Las Vegas, Department of Economics, November.

Deaton, A. (2009), “Aging, religion, and health". NBER Working Paper \#15271, Cambridge. 
Deaton, A. \& A. Stone (2013), Economic analysis of subjective well-being: Two happiness puzzles. $A E A$ Papers and Proceedings, 103(3), 591-597. http://dx.doi.org/10.1257/aer.103.3.591

Delle Fave, A., I. Brdar, \& D. Vella-Brodrick (2013), Religion, spirituality, and well-being across nations: The eudaemonic and hedonic happiness investigation. Cross Cultural Advances in Positive Psychology, 3, 117-134. http://dx.doi.org/10.1007/978-94-007-4611-4_8

Diener, E. (2012), "Do hedonic measures differ from cognitive evaluation measures of well-being?" Background Paper for National Academy of Sciences Panel on Well-Being Metrics and Public Policy, November.

Diener, E., L. Tay, \& D. G. Myers (2011), The religion paradox: If religion makes people happy, why are so many people dropping out? Journal of Personality and Social Psychology, 101(6), 1278-90. http://dx.doi.org/10.1037/a0024402

Ellison, C. (1991), Religious involvement and subjective well-being. Journal of Health and Social Behavior, 32(1), 80-99. http://dx.doi.org/10.2307/2136801

Frey, B. \& A. Stutzer (2002), Happiness and Economics (Princeton: Princeton University Press).

Graham, C. (2008), "The economics of happiness", in Steven Durlauf and David Blume, eds., The New Palgrave Dictionary of Economics, $2^{\text {nd }}$ Edition (London: Palgrave-MacMillan). http://dx.doi.org/10.1057/9780230226203.0702

Graham, C. (2009), Happiness around the world: The paradox of happy peasants and miserable millionaires (Oxford: Oxford University Press). http://dx.doi.org/10.1057/9780230226203.0702

Graham, C. (2012), "The distinctiveness of hedonic and evaluative well-being”. Background Paper for National Academy of Sciences Panel on Well-Being Metrics and Public Policy, November.

Graham, C. \& S. Chattopadhyay (2009), Well-being and public attitudes in Afghanistan: Some insights from the economics of happiness. World Economics, 10(3), 105-146.

Graham, C. \& S. Chattopadhyay (2013), Gender and well-being around the world. International Journal of Happiness and Development, 1(2), 212-232. http://dx.doi.org/10.1504/IJHD.2013.055648

Graham, C., S. Chattopadyay, \& M. Picon (2010), “The Easterlin and other paradoxes: Why both sides of the debate may be correct", in Ed Diener, John Helliwell, and Daniel Kahneman, eds. International Differences in Well-Being (Oxford: Oxford University Press). http://dx.doi.org/10.1093/acprof:oso/9780199732739.003.0009

Graham, C. \& M. Nikolova (2013), “Happy peasants and frustrated achievers? Agency, capabilities, and subjective well-being", Human Capital and Economic Opportunity Working Papers, No. 13, University of Chicago, Department of Economics.

Huang, C.-Y.M.-C. H., \& T.-J. Chen (2012), An exploratory study of religious involvement as a moderator between anxiety, depressive symptoms, and quality of life outcomes. Journal of Clinical Nursing, (April), 18-24.

Kahneman D. \& A. Deaton (2010), High income improves evaluation of life but not emotional well-being. Proceedings of the National Academy of Sciences, 107, 16489-16493.

http://dx.doi.org/10.1073/pnas.1011492107

Kennedy, J. \& H. Kanthamani (1995), “Empirical Support for a Model of Well-being, Meaning in Life, Importance of Religion, and Transcendent Experiences", http://jeksite.org/research/path.pdf

Koenig, H., J. Kvale, \& C. Ferrel (1998), Religion and well-being later in life. The Gerontologist, 28(1), 1828. http://dx.doi.org/10.1093/geront/28.1.18

Koenker, R. \& K. F. Hallock (2001), Quantile regression. The Journal of Economic Perspectives, 15(4), $143-$ 156. http://dx.doi.org/10.1257/jep.15.4.143

Lelkes, O. (2002) “Tasting Freedom: Happiness, Religion, and Economic Transition”, Center for Analysis of Social Exclusion Working Paper \# 59, London School of Economics.

Levin, J. (2013), Religion and mental health among Israeli Jews: Findings from the SHARE-Israel Study. Social Indicators Research, 113, 769-784. http://dx.doi.org/10.1007/s11205-012-0113-x

Lim, C. \& R. Putnam (2010), Religion, social networks, and life satisfaction. American Sociological Review, 75(6), 914-933. http://dx.doi.org/10.1177/0003122410386686

McFadden, S. (1995), Religion and well-being in aging persons in an aging society. Journal of Social Issues, 51(2), 161-175. http://dx.doi.org/10.1111/j.1540-4560.1995.tb01329.x 
Mookerjee, Rajen and Krista Beron (2005), Gender, religion, and happiness. Journal of Socioeconomics, 34, 674-685. http://dx.doi.org/10.1016/j.socec.2005.07.012

Popova, O. (2010), "Can religion insure against aggregate shocks to happiness? The case of the transition economies". CERGE-EI Working Paper \#425, Academy of Sciences of the Czech Republic, Prague, October.

Steiner, L., L. Leinart, \& B. Frey (2010), Economics, religion, and happiness. Journal for Business, Economics and Ethics, (published in German) 11(1), 45-64.

Stone, A. \& C. Mackie, eds. (2013), Subjective well-being: Measuring happiness, suffering, and other dimensions of experience (Washington, D.C.: The National Academies Press).

Witter, R. A., W. Stock, M. Okun, \& M. Haring (1985), Religion and subjective well-being in adulthood: A quantitative synthesis. Review of Religious Research, 26(4), 332-342. http://dx.doi.org/10.2307/3511048 


\section{Appendix: Summary statistics and variable descriptions}

\begin{tabular}{|c|c|c|c|c|}
\hline Variable & Description & Observations & Mean & Std. Dev. \\
\hline BPL & Life today on a $0-10$ best possible life scale: $10=$ Best $0=$ Worst & $1,049,206$ & 5.468 & 2.200 \\
\hline Happy & Did you experience happiness yesterday? $1=$ Yes, $0=\mathrm{No}$ & 790,469 & 0.699 & 0.459 \\
\hline Religion Important & Is religion an important part of your daily life? $1=\mathrm{Yes}, 0=\mathrm{No}$ & 921,359 & 0.737 & 0.440 \\
\hline Religious Service & $\begin{array}{l}\text { Did you attend a religious service in the past seven days } \\
\text { outside a wedding or other ceremony? } 1=\text { Yes, } 0=\mathrm{No}\end{array}$ & 616,271 & 0.488 & 0.500 \\
\hline Urban & $\begin{array}{l}\text { Respondent's household location: } 1=\text { Urban (large city or } \\
\text { suburb) } 0=\text { Other }\end{array}$ & 940,548 & 0.456 & 0.498 \\
\hline Household Size & Household adult size (Number of persons aged 15 or above) & 930,493 & 3.257 & 1.913 \\
\hline Log Income & Ln(Household income) & 815,554 & 8.844 & 1.457 \\
\hline Gender & Gender: $1=$ Female $0=$ Male & $1,072,127$ & 0.535 & 0.499 \\
\hline Age & Age (in years) & $1,064,773$ & 40.143 & 17.174 \\
\hline Married & $\begin{array}{l}\text { Marital status: } 1=\text { Married or in a domestic partnership } \\
0=\text { Other }\end{array}$ & $1,041,261$ & 0.584 & 0.493 \\
\hline Education & Respondent's education: $1=\mathrm{HS}$ and above $0=$ Less than HS & 979,003 & 0.147 & 0.354 \\
\hline Christian & Religion - Christian, denomination not specified: $1=\mathrm{Yes}, 0=\mathrm{No}$ & 876,574 & 0.064 & 0.245 \\
\hline & $\begin{array}{l}\text { Includes Chinese Traditional Religion/Confucianism, Sikhism, } \\
\text { Juche, Spiritism, Bahai, Jainism, Shinto, Cao Dai, } \\
\text { Zoroastrianism, Tenrikyo, Neo-Paganism, Unitarian- }\end{array}$ & 876,574 & 0.013 & 0.115 \\
\hline Other Religion & Universalism, Rastafarian, Scientology, Taoism, Daoism & & & \\
\hline Catholic & Religion - Roman Catholic, Catholic Christian: $1=\mathrm{Yes}, 0=\mathrm{No}$ & 876,574 & 0.238 & 0.426 \\
\hline Protestant & $\begin{array}{l}\text { Religion - Protestant, Anglican, Methodist Christian: 1=Yes, } \\
0=\text { No }\end{array}$ & 876,574 & 0.134 & 0.341 \\
\hline Orthodox & Religion - Eastern Orthodox, Orthodox Christian: $1=$ Yes, $0=\mathrm{No}$ & 876,574 & 0.081 & 0.272 \\
\hline Muslim & Religion - Muslim: $1=$ Yes, $0=\mathrm{No}$ & 876,574 & 0.211 & 0.408 \\
\hline Shiite & Religion - Shiite Muslim: $1=\mathrm{Yes}, 0=\mathrm{No}$ & 876,574 & 0.019 & 0.136 \\
\hline Sunni & Religion - Sunni Muslim: $1=$ Yes, $0=\mathrm{No}$ & 876,574 & 0.077 & 0.267 \\
\hline Druze & Religion - Druze: $1=$ Yes, $0=\mathrm{No}$ & 876,574 & 0.001 & 0.032 \\
\hline Hindu & Religion - Hindu: $1=$ Yes, $0=\mathrm{No}$ & 876,574 & 0.040 & 0.195 \\
\hline Buddhist & Religion - Buddhist: $1=Y e s, 0=\mathrm{No}$ & 876,574 & 0.052 & 0.221 \\
\hline Indigenous & Religion - Indigenous/African Traditional: $1=$ Yes, $0=\mathrm{No}$ & 876,574 & 0.003 & 0.057 \\
\hline Judaism & Religion - Jew: $1=$ Yes, $0=\mathrm{No}$ & 876,574 & 0.007 & 0.084 \\
\hline NonReligious & $\begin{array}{l}\text { Religion - Secular, Nonreligious, Agnostic, Atheist: 1=Yes, } \\
0=\text { No }\end{array}$ & 876,574 & 0.060 & 0.238 \\
\hline Cincwdi & WDI Country Income Level: 1= Low, 2=Middle, 3=High & $1,071,705$ & 2.101 & 0.677 \\
\hline Social1 & $\begin{array}{l}\text { Hours spent with friends and family each day, } 0-4 \text { hours: } \\
1=\text { Yes, } 0=\text { No }\end{array}$ & 252,545 & 0.560 & 0.496 \\
\hline Social2 & $\begin{array}{l}\text { Hours spent with friends and family each day, 5-9 hours: } \\
1=\text { Yes, } 0=\text { No }\end{array}$ & 252,545 & 0.271 & 0.444 \\
\hline Social3 & $\begin{array}{l}\text { Hours spent with friends and family each day, } 10-14 \text { hours: } \\
1=\text { Yes, } 0=\text { No }\end{array}$ & 252,545 & 0.116 & 0.321 \\
\hline Social4 & $\begin{array}{l}\text { Hours spent with friends and family each day, } \\
\text { More than } 15 \text { hours: } 1=\text { Yes, } 0=\text { No }\end{array}$ & 252,545 & 0.053 & 0.223 \\
\hline Social1religious & Interaction between social1 and religious service attendance & 234,553 & 0.288 & 0.453 \\
\hline Social2religious & Interaction between social 2 and religious service attendance & 234,553 & 0.137 & 0.344 \\
\hline Social3religious & Interaction between social 3 and religious service attendance & & & \\
\hline Social4religious & Interaction between social4 and religious service attendance & 234,553 & 0.023 & 0.150 \\
\hline
\end{tabular}

Note: The World Development Index (WDI) Income Levels breakdowns are: low income (18.36\%); middle income (53.20\%); and high income (28.44\%). 